Interdiscip Toxicol. 2016; Vol. 9(2): 39-54. doi: 10.1515/intox-2016-0006

Copyright @ 2016 SETOX \& IEPT, SASC

This is an Open Access article distributed under the terms of the Creative Commons Attribution License (http://creativecommons.org/licenses/by/2.0), which permits unrestricted use, distribution, and reproduction in any medium, provided the original work is properly cited.

\title{
REVIEW ARTICLE Predicting disease onset in clinically healthy people
}

\author{
Harold I. ZELIGER \\ Zeliger Research \& Consulting, Cape Elizabeth, ME 04107, USA
}

ITX090216A01 • Received:20 February 2016 • Revised:12 April 2016 • Accepted: 17 April 2016

\begin{abstract}
Virtually all human disease is induced by oxidative stress. Oxidative stress, which is caused by toxic environmental exposure, the presence of disease, lifestyle choices, stress, chronic inflammation or combinations of these, is responsible for most disease. Oxidative stress from all sources is additive and it is the total oxidative stress from all sources that induces the onset of most disease. Oxidative stress leads to lipid peroxidation, which in turn produces Malondialdehyde. Serum malondialdehyde level is an additive parameter resulting from all sources of oxidative stress and, therefore, is a reliable indicator of total oxidative stress which can be used to predict the onset of disease in clinically asymptomatic individuals and to suggest the need for treatment that can prevent much human disease.
\end{abstract}

KEY WORDS: disease prediction; disease prevention; disease mechanism; environmental disease; infectious disease

\section{Introduction}

The incidence of disease world wide is continually increasing. Though people are living longer, we are also living sicker and with increasing numbers of multi-morbid diseases (Murray et al., 2015; Zeliger, 2014; Wallace \& Salive, 2013; 2012; Pritchard \& Rosenorn-Lanng, 2015). As an example of this phenomenon, in the United States, the percentage of people with multi-morbid diseases has increased from $37.2 \%$ of the population in the year 2000 to $45.3 \%$ of the population in 2010 (Freid et al., 2012).

Numerous diseases have reached epidemic and pandemic proportions in the past two generations. The dramatic increase of environmental disease prevalence with time can be seen from plots of disease percent increases versus time, from 1940 s to 2010 . Such plots produce hyperbolic curves such as that in Figure 1. Examples of diseases that fit this plot include autism and autism spectrum disorders (Zeliger, 2013b), type 2 diabetes (Zeliger, 2013), obesity (Wang \& Beyoun, 2007) childhood cancers (Parkin et al., 1988), onset of dementia and other neurological diseases (Zeliger, 2013b), and both male and female infertility (Colborn et al., 1996). The slopes of these curves exactly correspond to those of plots for

\footnotetext{
Correspondence address:

chemical production and use versus time, as exemplified by data for synthetic chemical production (Neel \& Sargis, 2011), increased pesticide use (Chen \& McCarl, 2001), increased world wide energy production from combustion of fossil fuel use, increases in air and water pollution (U.S. Energy Information Administration, 2014), and increases in pharmaceutical use (Kantor et al., 2015).

Free radicals are essential for homoeostasis and are generated as byproducts of normal metabolic cellular activities (Bhattarcha et al., 2014). Oxidative stress (OS) ensues when the production of free radicals, reactive oxygen species (ROS) and reactive nitrogen species ( $\mathrm{RON}$ ) occurs at a pace faster than the body's antioxidant production. Exposures to toxins as well as the presence of disease results in increases in these free radical species and produce the oxidative imbalances in cells that produce OS. OS is. as is shown below, directly or indirectly, the cause of virtually all disease. It leads to attack on macromolecules, induction of cell death via apoptosis or necrosis and structural tissue damage, including lipid peroxidation (LP) (Lorente, 2013).

OS is directly responsible for non-communicable environmental disease (ENVD) (Davies, 1995; Zeliger \& Lipinski, 2015; Bhutia et al., 2014), and indirectly responsible for the spread of infectious disease (INFD) via undermining of the immune system (Zaki et al., 2005; Valyl-Nagy \& Dermody, 2005; CDC, 2015). The many causes of oxidative stress in humans include: absorption of exogenous toxic chemicals and chemical mixtures (Zeliger, 2003; Zeliger \& Lipinski, 2015); exposure to 


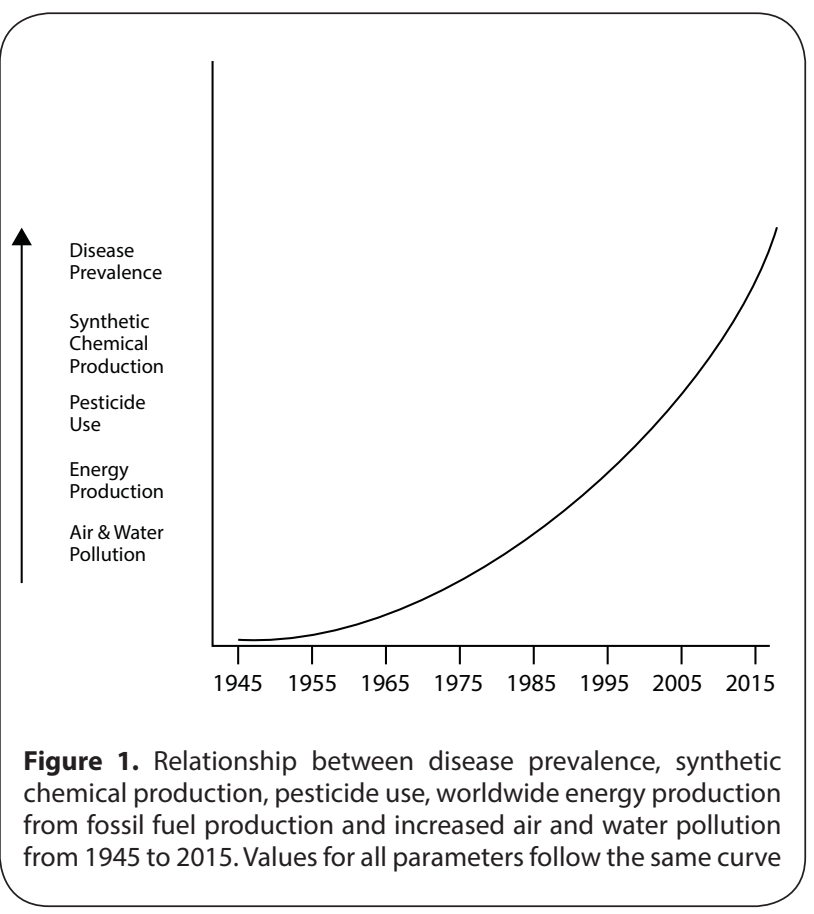

ionizing, ultra violet and radio frequency radiation (Semenkov, 2015; Tominaga et al., 2004; Dasdag et al., 2012); diet, including fructose, triglycerides, processed and red meat, artificial flavors and colors, preservatives (Brkic, 2010; Cui et al., 2012 Elgazar, 2013; Lustig et al; 2015); tobacco use (Nielsen et al., 1997; Pham-Huy et al., 2008; Sudha et al., 2015); alcohol consumption (Nielsen et al., 1997; Deshpande et al., 2014); pharmaceutical use (Kantor et al., 2015; Dwyer et al., 2014; Bhattacharya et al., 2014); prior illness (Zeliger, 2014); obesity (KarbownikLewinska, 2014; Olusi, 2002; Jain \& Chaves, 2011; Sankhka et al., 2012); psychological stress (Chaput et al., 2013; Halonen et al., 2015; Aich et al., 2009); and physical trauma (Miller \& Sadeh, 2014; Faden \& Loane, 2015).

The 10 leading causes of death in the United States in 2013, as reported by the Centers For Disease Control (CDC, 2015) and the percentages of each, are:

$\begin{array}{ll}\text { Heart disease } & 32 \% \\ \text { Cancer } & 31 \% \\ \text { Chronic lower respiratory diseases } & 8 \% \\ \text { Accidents } & 7 \% \\ \text { Stroke } & 7 \% \\ \text { Alzheimer's disease } & 4 \% \\ \text { Diabetes } & 4 \% \\ \text { Influenza and pneumonia } & 3 \% \\ \text { Liver disease } & 2 \% \\ \text { Suicide } & 2 \%\end{array}$

Of these causes of death, $91 \%$, of all the diseases on this list, (as is shown below) are directly attributable to OS. Though no data exist, one could argue that a sizable portion of the remaining $9 \%$ (accidents and suicide) could be attributed to psychological stress, a known cause of OS.
OS causes disease via one of 4 pathways. These are: protein oxidation, DNA oxidation, lipid peroxidation and oxidative modification of sugars (Ogino \& Wang, 2007). Of these, lipid peroxidation is the most indicative, as cell penetration by toxic agents initially requires the breeching lipophilic cell membranes (Zeliger, 2003; Zeliger, 2011; Zeliger \& Lipinski, 2015). Such reactions produce fatty acid degradation fragments that are biomarkers for the presence of OS. Malondialdehyde (MDA) is the biomarker most reliably used to indicate the presence of disease and toxic exposure (Nielsen et al., 1997; Lorente et al., 2013; Tangvarasittichai et al., 2009; Sudha et al., 2014). Elevated levels of MDA have been shown to be present in the serum of patients with elevated OS and increased concentration of MDA accordingly is widely used as an indicator of the presence of disease in humans, with the severity of disease being a function of MDA level in a dose response relationship (Nielsen et al., 1997; Zhu et al., 2005; Romeau et al., 2008; Aflanie et al., 2015; Agarwal et al., 1987; Ayala et al., 2014).

As elevation of serum MDA can be caused by exposures as well as by disease, it is proposed here that serum MDA levels can be used to predict the onset of disease in people who are seemingly clinically healthy.

\section{Methods}

The hypothesis reported here is based upon a literature review of numerous published studies, both by this author and many others on oxidative stress and disease and on biomarkers for OS.

\section{Results}

\section{Causes of $0 \mathrm{~S}$}

There are numerous causes of oxidative stress. These include: exposures to chemicals, heavy metals, particles, fibers, foods and food additives, pharmaceuticals, ionizing and non-ionizing radiation, psychological stress, physical trauma and the presence of other disease (Zeliger \& Lipinski, 2015). Table 1 contains a representative list of these causes of OS.

\section{Chemicals}

Chemicals that cause OS include polychlorinated biphenyls (PCBs), dioxins and furans, widely distributed in the environment as a result of combustion, industrial processes and commercial applications; organochlorine pesticides such as DDT, polybrominated diphenyl ethers (PBDEs), commonly used as fire retardants in children's clothing and upholstery; phthalates, widely used in cosmetics and other personal care products; bis-phenol A, found in plastics used as eating utensils and food containers; by products in drinking water resulting from disinfection of potable water; polynuclear aromatic hydrocarbons, resulting from fossil fuel combustion and tobacco smoke; low molecular weight hydrocarbons such 
as benzene, toluene, xylene and hexane from gasoline vaporization and incorporation into adhesives; alcohol; paints and other products; heavy metals, including mercury, cadmium, lead, chromium, copper and others arising from mining and industrial usage; and numerous other species. (Patterson et al., 2009; Zeliger, 2014; Azeez et al., Adedara et al., 2014; Lodovici \& Bigagli, 2011; 2015; Pan et al., 1987; Kambia et al., 2011; Yang et al., 2009; Kaur et al., 2014; Zeliger \& Lipinski, 2015; Patil etal., 2006; Li et al., 2004; Zeliger, 2003; Zeliger, 2011; Pals et al., 2013; Bhattacharyya et al., 2014; Ayala et al., 2014; Doi \& Uetsuka, 2012; Lodovici \& Bigagli, 2011; Gong et al., 2013; PhamHuy etal., 2008; Luongo et al.,2015; Knaapen et al., 2004; Donaldson et al., 2005); (Veraldi et al.,2006; Schneider et al., 2008; Liu et al., 2009; Banerjee et al., 1999; Jeng et al., 2011; Bagaiktar et al., 2008).

\section{Chemical mixtures}

Until recently, the impacts of absorption of chemical mixtures have been largely limited to considerations of additive effects. It is now known, however, that exposures to mixtures of lipophilic and hydrophilic species facilitates the absorption of hydrophilic species that would otherwise not absorb and that exposures to such mixtures induces attacks on organs not known to be attacked by the individual components of such mixtures (Zeliger, 2003; Zeliger, 2011). It has been recently been reported that aromatic lipophilic species can also transport OS inducing heavy metals through lipophilic cell membranes (Zeliger \& Lipinski, 2015). It is, therefore, to be anticipated that exposures to chemical mixtures will result in increased OS and in MDA serum levels in excess of those expected from exposure to the individual species that comprise such mixtures. An example of this phenomenon is the reported finding that exposures to mixtures of pesticides result in increased OS (Fukuyama et al., 2014).

Another effect of exposure to mixtures is contributing to meeting the hallmarks necessary for the onset of disease. Multiple hallmarks of aging (Meiners et al., 2014), cancer onset (Nahta et al., 2015), type 2 diabetes (Thiering \& Heinrich, 2015), asthma (Delfino et al., 2013), cardovascular disease (Li et al., 2015) and Alzheimer's disease (Cabezas-Opazo et al., 2015) have been identified. In these studies, the authors conclude that different chemical exposures affect different specific hallmarks and that exposures to mixtures can account for the onset of disease. All of the chemicals identified in these studies are known to induce OS. What remains to be addressed are the effects of specific chemical mixtures on individual hallmarks of disease and their effect on OS when compared to the effects of the individual components of such mixtures. Given the constant exposure of humanity worldwide to multiple chemical mixtures, the parameters of such studies require careful planning in order to produce meaningful results.

\section{Particles and fibers}

Particles and fibers that cause OS include asbestos, used in automobile brakes, fire-retardant materials, and
Table 1. Causes of oxidative stress.

\begin{tabular}{l} 
CHEMICALS \\
Polychlorinated biphenyls \\
Organchlorine pesticides \\
Polybrominated diphenyl ethers \\
Dioxins \\
Furans \\
\hline Polynuclear aromatic hydrocarbons \\
\hline Low molecular weight hydrocarbons \\
\hline Phthalates \\
\hline Bis-phenol A \\
Heavy metal ions \\
Disinfection by products \\
Lipid peroxidation products \\
Mycotoxins \\
\hline Air pollution \\
\hline Tobacco smoke \\
Textile chemicals \\
Chemical mixtures
\end{tabular}

PARTICLES AND FIBERS

Asbestos

Silica

Fly ash

Synthetic mineral fibers

Nanoparticles

\section{FOODS AND FOOD ADDITIVES}

Animal fats

Processed meat

Red meat

Fructose

Artificial colors

Artificial flavors

Extraction solvents

Preservatives

RADIATION

lonizing radiation

Ultraviolet radiation

$900 \mathrm{MHz}$ radio frequency radiation.

\section{PHARMACEUTICALS}

Antiboiotics

Antidepressants

NSAIDs

TNF inhibators

\section{PSYCHOLOGICAL STRESS}

Emotional stress, anxiety and depression

Sensory offenders

Circadian cycle interruption

Sleep deprivation and insomnia

Excessive heat exposure

PHYSICAL TRAUMA

Chronic traumatic encephalopathy 
heat insulators; silica resulting from mining; concrete formulations and grinding; fly ash that emanates from combustion of coal; synthetic fibers used in clothing; and nanoparticles from industrial processes, combustion and the deliberate production for use in industrial, consumer and pharmaceutical products (Donaldson et al., 1998; Ning et al., 2003; Deshpande et al., 2002; Browne et al., 2011; Jaurand \& Pairon, 2011; Steenland \& Stayner, 1997).

\section{Diet and food additives}

Ingestion of some foods gives rise to OS. These include processed meats and red meat (Bovalino et al., 2016; Bouvard et al., 2015); fructose from refined sugar and high fructose corn syrup (Lustig et al., 2015; Basaranoglu et al., 2015; Park et al., 2013); synthetic chemicals used as artificial food colors and flavors including preservatives such as butylated hydroxyanisole (BHA), butylated hydroxytoluene (BHT), calcium proprionate, triclosan, and parabens (Abdel-Salam et al., 2012; El-Wahab \& Moram, 2013; Stevens et al., 2013; Cemek et al., 2014); solvents such as toluene used to extract flavors and colors from natural products and to produce synthetic food additives; and chemicals such as phthalates and bisphenol A used in food packaging and which leach out into foods. (Zeliger, 2011).

\section{Radiation}

OS is caused by exposure to ionizing radiation from $\mathrm{x}$-rays, exposure to radioactive isotopes, ultraviolet radiation and microwave radiation; as well as by exposure to non-ionizing radiation such as that from $900 \mathrm{MHz}$ radio frequency waves commonly used for cell phone signal transmission (Esmekaya et al., 2011;Semenkov et al., 2015; Tominaga et al., 2004; Dasdag et al., 2012; Kim et al., 2011).

\section{Drugs and pharmaceuticals}

Many pharmaceuticals, examples of which are: commonly prescribed antibiotics, antipsychotics, antidepressants, drugs used to combat hypertension and NSAIDs (including widely used acetaminophen), cause OS as do alcohol and recreational drugs (Kantor et al., 2015; Rodayan, 2016; Knight, 2003; Dwyer et al., 2014; Kalghatgi et al., 2013; Nunes et al., 2006; Deavall et al., 2012; Benotti et al., 2009; Bhattacharyya et al., 2014; Neustadt \& Pieczenik, 2006; Csoka and Szyf, 2009).

\section{Psychological stress}

Psychological stress is a common cause of OS (Ramanathan et al., 2002), as are exposures to sensory offenders, circadian cycle interruption, sleep deprivation and insomnia and excessive exposure to heat (Chaput et al., 2013; Halonen et al., 2015; Noguti et al., 2013, McEwen, 2006). Psychological stress is associated with reduced immune system function, higher incidence and greater severity of infectious disease (Aich et al., 2009). Psychological stress and OS are bidirectional with each a cause of the other (Bouayed et al., 2009). For example, increased OS makes one more susceptible to viral disease such as the common cold and infectious illness induces psychological stress
(Cohen et al., 2015). Chronic psychological stress also induces chronic inflammation which mediates chronic disease and has been linked to cancer, diabetes, cardiovascular, neurological, respiratory and other diseases. (Salzano et al., 2014; Reuter et al., 2010; ; Khansari et al., 2009; McEwen, 2006; Semenkov et al., 2015).

\section{Physical stress}

Physicalstressintheformofexposuretoexcessheat(Mujahid et al., 2007; Reuter et al., 2010; Kaldur et al., 2014; Kim et al., 2015), chronic inflammation (Khansari et al., 2009; Tremellen, 2008) or chronic physical trauma, an example of which is chronic traumatic encephalopathy (CTE) (Miller \& Sadeh, 2014; Faden \& Loane, 2015), all cause OS.

\section{OS and disease}

Oxidative stress has been associated with chronic inflammation and numerous diseases (Reuter et al., 2010). Table 2 contains a representative list of diseases known to be caused by OS. These include non-contagious environmental diseases (ENVDs), examples of which are: metabolic (Bhutia et al., 2014; Tangsvarasittichai et al., 2009; Yang et al., 2008; Zeliger, 2013), respiratory (Alsamarai et al., 2009; Corradi et al, 2003; Stupnytska, 2014; Zeliger et al., 2012), neurological (Davies, 1995; Baipai et al., 2014; Bulut et al., 2007; Zeliger, 2013b; Zeliger, 2015), endocrine (Torun et al., 2009; Vitale et al., 2013; Colborn et al., 1996), cardiovascular, (Boaz et al., 1999; Davies, 1995; Zeliger, 2013a; Neustadt \& Pieczenik, 2008; He \& Zuo, 2015; Kayama et al., 2015; Griendling \& Fitzgerald, 2003), gastrointestinal (Mete et al., 2013; Suzuki H et al., 2012; Kim et al., 2012), musculoskeletal, (Mete et al., 2013; Suzuki H et al., 2012; Kim et al., 2012), urinary tract (Kurutas et al., 2005).Merendino et al., 2003; Aryal et al., 2007), kidney (Forbes et al., 2008; Adedara et al., 2014; Galle, 2001), liver (Adedara et al., 2014; Cichoz-Lach \& Michalak, 2014; Webb \& Twedt, 2008), skin (Bickers \& Athar, 2006; Trouba et al., 2002; Okayama, 2005), immunological and autoimmune (Hughes, 1991; Jeng et al., 2011; Davies, 1995; Lou et al.; 2013; Lou et al., 3013; Bashir et al., 1993; Kumagai et al., 2003; Kalkan et al., 2014; Zeliger et al.; 2012; Zeliger et al., 2015), eye (Williams, 2008; Kruk et al., 2015), and periodontal diseases, (Liu et al., 2014), as well as obesity (Olusi, 2002; Sankhla et al., 2012; Jain \& Chaves, 2011; Zeliger, 2014; Fernandez-Sanchez et al., 2011; Manna \& Jain, 2015), and numerous cancers (Federico et al., 2007; Guven et al., 1999; Brown \& Bicknell, 2001; Dillioglugh et al., 2012; Chole et al., 2010; Taysi ert al., 2003; Salzman et al., 2009; Bitla et al., 2011; Reuter et al., 2010; Khansari et al., 2009). The list also includes infectious bacterial and viral diseases (INFDs) which are indirectly caused as a result of the undermining of the immune system by OS (Hughes, 1998; Bouhafs, 1999; Cemek et al., 2005; Zaki, 2005; Rajah \& Chow, 2015).

OS does not directly cause infectious diseases, but does so indirectly by undermining the functioning of the immune system via immuno-suppression (Hughes, 1999; Akaike, 2001; Xu et al., 2015; Splettstoesser \& SchuffWerner, 2002). It is to be noted that all the chemicals 
listed in Table 1 are immuno-suppressants (Veraldi et al., 2006; Patterson \& Gerrmolec, 2006). These include: polynuclear aromatic hydrocarbons (Jeng et al., 2011), dioxins (Schneider et al., 2008), tobacco smoke (Arcavi \& Benowitz, 2004), pesticides (Banerjee et al., 1999) and heavy metals (Liu et al., 2009). Phagocytes generated when the body responds to infectious agents cause further free radical generation resulting from lipid peroxidation, thus adding to OS (Bouhafs \& Jastrand, 1999; Stossel at el. 1974). It has been reported that higher levels of OS further infectious disease in critically ill patients Andresen et al., 2006).

OS also leads to infectious diseases by impacting the actions of gut microbia. The following examples illustrate this: Air pollution (Salim et al., 2013;), PCBs (Choi et al., 2010) and diets chronically high in fat (Qiao et al., 2013) increase OS in the gut causing membrane damage that leads to increased permeability and translocation of gut bacteria with ensuing disease (Guarner \& Soriano, 2005;). Though not a disease, malnutrition is also known to lead to OS and immune system malfunction (Darmon et al., 1993; Katona \& Katona-Apte, 2008; Ghone et al., 2013).

\section{Obesity}

Obesity is a chronic low-grade inflammatory disease which gives rise to OS (Vandanmagasar et al., 2011; Karbownik-Lewinska et al., 2012; Liu et al., 2014) and predisposes the onset of illness (Stokes \& Preston, 2015). Obesity increases the risk for numerous diseases via impact on the immune system. For example, it is associated with increased susceptibility to infections such as the flu (Olusi, 2002; Falagas \& Kompoti, 2006; Jain \& Chaves, 2011) and promotes the onset of metabolic syndrome and diabetes (Furukawa et al., 2004; Vu et al., 2015). OBS is indirectly responsible for shortened life spans, with death coming from subsequent diseases. It is estimated that OBS shortens life by between 8 and 14 years (Kitahara et al., 2014; Grover et al., 2014). The world-wide obesity epidemic is a recent phenomenon that corresponds to the exponential production and wide-spread distribution of synthetic chemicals, essentially all of which are known to induce OS (Bailie-Hamilton, 2002).

Obesity plays a key role in multi-morbidity of disease. The quantity of white adipose tissue (WAT) is dramatically increased with obesity. WAT serves as a collector of absorbed exogenous lipophilic chemicals, all of which are known to cause OS, obesity and disease. Diseases such as type 2 diabetes cause the absorption of exogenous lipophiles. Obesity is known to cause ENVDs and ENVD's have been shown to cause obesity. This sets up what has been termed the OBESITY-LIPOPHILE-DISEASE triangle (Zeliger, 2014), which is depicted in Figure 2 and reproduced with permission. The interconnection between the three parameters of this triangle is as follows: Firstly, exogenous lipophilic chemical absorption causes environmental diseases. Conversely, environmental diseases, T2D, for example, cause the absorption of exogenous lipophiles. Secondly, obesity causes environmental diseases and environmental diseases cause

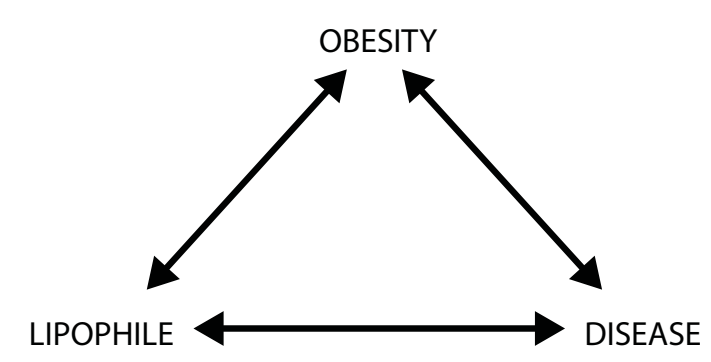

Exogenous lipophiles cause environmental diseases. Environmental diseases, T2D, for example, cause the absorption of exogenous lipophiles.

Obesity causes environmental diseases. Environmental diseases cause obesity.

Exogenous lipophiles cause obesity.

Obesity promotes the absorption of exogenous lipophiles.

Figure 2. Obesity-lipophile-disease triangle, reprinted with permission (Zeliger, 2014).

\begin{tabular}{|c|c|c|c|c|c|c|c|c|c|c|}
\hline \multirow[t]{2}{*}{ T2D } & $x$ & $x$ & $x$ & $X$ & $X$ & $X$ & $X$ & $x$ & $x$ & $X$ \\
\hline & CVD & $X$ & $X$ & $X$ & $X$ & $X$ & $X$ & $X$ & $X$ & $X$ \\
\hline & & NRD & $x$ & $x$ & $x$ & $x$ & $x$ & $x$ & $x$ & \\
\hline & & & NDV & & $X$ & $x$ & $x$ & & $x$ & $x$ \\
\hline & & & & NDG & $x$ & & & & & $x$ \\
\hline & & & & & MSK & $X$ & $x$ & $x$ & $x$ & $X$ \\
\hline & & & & & & IMM & $x$ & $x$ & & \\
\hline & & & & & & & RES & $x$ & $x$ & $x$ \\
\hline & & & & & & & & CMS & $x$ & \\
\hline & & & & & & & & & OBS & $X$ \\
\hline & & & & & & & & & & CAN \\
\hline
\end{tabular}

Figure 3. Co-morbidities of chemically induced environmental diseases, reprinted with permission (Zeliger, 2014). X denotes the existence of co-morbidity between the two diseases. Abbreviations: T2D - type 2 diabetes; CVD - cardiovascular disease; NRD - neurological disease; NDV - neurodevelopmental disease; NDG - neurodegenerative disease; MSK - musculoskeletal disease; IMM - immunological disease; RES - respiratory disease; CMS - chemical sensitivity; OBS - obesity; CAN - cancer.

obesity. Thirdly, exogenous lipophiles cause obesity and obesity promotes the absorption of exogenous lipophiles.

\section{Multi-morbiidity}

It has been definitively established that the onset of disease leads to multi-morbidity (Zeliger et al., 2012; Zeliger, 2014). A preponderance of the diseases listed in Table 2 are co-morbid with each other. This is demonstrated by the co-morbidity diagram in Figure 3 (reproduced with permission) (Zeliger, 2014). The number of multimorbidities a person can experience has been found to range between 4 and 10 in a study of multi-morbidities in chemically sensitive individuals. Figure 3 is demonstrative of this (Zeliger et al., 2012). It is to be noted that the diseases listed in Table 2 are also causes of OS and that 
Table 2. Environmental and infectious diseases caused by oxidative stress.

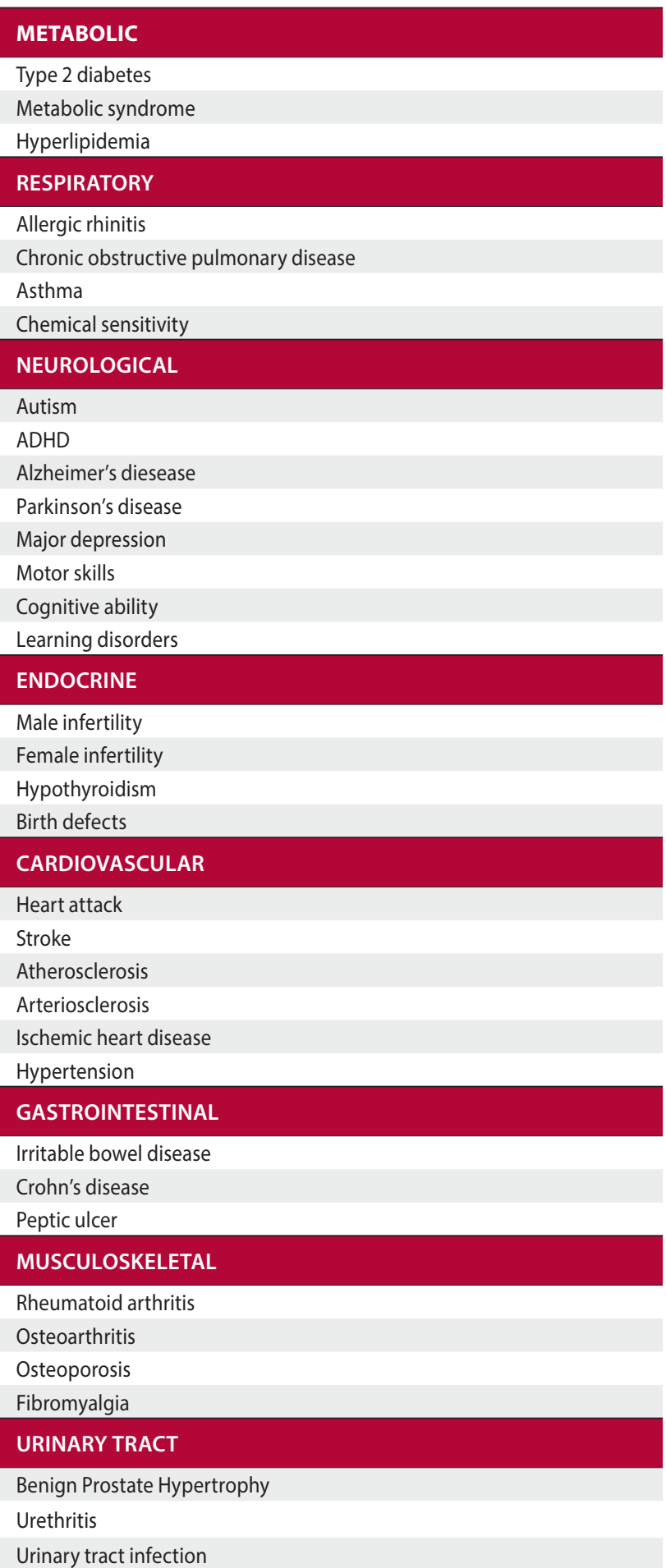

\section{KIDNEY}

End stage renal disease

Renal vascular disease

Glomeruolsclerosis

LIVER

Cirrhosis

Hepatitis

Fatty liver disease

\begin{tabular}{l} 
SKIN \\
Psoriases \\
Eczema \\
SLE (lupus) \\
Dermatitis \\
Acne \\
\hline IMMUNOLOGICAL AND AUTOIMMUNE \\
\hline ALS \\
Acute uticaria \\
Chronic fatigue syndrome \\
Chemical sensitivity \\
Lupus \\
Sjogram's syndrome \\
EYE DISEASES
\end{tabular}

\section{Cataracts}

Glaucoma

Macular degeneration

Corneal and conjunctive diseases

PERIODONTAL
Chronic periodontitis
OBESITY

\begin{tabular}{l} 
CANCER \\
Virtually all cancers \\
Metastasis \\
VIRAL AND BACTERIAL INFECTIOUS DISEASES \\
Herpes \\
Influenza \\
Common cold \\
\hline TB \\
Herpes \\
HIV and AIDS \\
\hline
\end{tabular}

the onset of disease is a causative factor in the onset of co-morbidity (Zeliger, 2014).

People with ENVDs have high incidences of other ENVDs and INFDs as well. Those with INFDs have high incidences of INFDs as well as ENVDs. Thus, it has been reported that co-morbidities exist between most of the diseases in Table 2 (Zeliger, 2014) and between numerous INFDs (Andresen et al., 2006). Examples of co-morbidities between ENVDs and INFDs include: the flu and neurological disorders (CDC, 2015a; Blanton et al., 2012); Alzheimer's disease and viral infections (Honjo et al., 2009; Maheshwari \& Eslick, 2015; Starakis et al., 2011); HIV and type 2 diabetes (Moni \& Lio, 2014); HIV tuberculosis and malaria with type 2 diabetes (Marais et al., 2013); cardiovascular disease and COPD in a bidirectional manner (Oni \& Unwin, 2015); chronic infections with heart disease (Madjid et al., 2004); and type 2 diabetes with hepatitis C (Guo et al., 2013). 


\section{OS and aging}

Though a natural consequence of living, aging is accelerated by excessive OS. A widely held theory is that OS within mitochondria damages the mitochondria, which in turn leads to the production of increased quantities of ROS which cause further damage. Once it starts, this cycle leads to further damage and corresponding aging (Romano et al., 2010). OS has been shown to shorten telomere length (Kawanishi \& Oikawa, 2004; von Zglinicki, 2002;). Telomeres are repetitive DNA sequences at the ends of eukarytic chromosomes that are shortened in each somatic cell division. Reduced telomere length is associated with aging and with the onset of cancer and other age-related diseases (Epel et al., 2004; Hou et al., 2015;). Lowering of OS, however, has been shown to delay the shortening of telomere length and thus prolong life and reduce cancer incidence (Crous-Bou et al., 2014).

Nine hallmarks of aging have been identified (LopezOtin et al., 2013; Meiners et al., 2015). These are:

- genomic instability

- telomere attrition

- epigenetic alterations

- loss of proteostasis

- deregulated nutrient-sensing

- mitochondrial dysfunction

- cellular senescence

- stem cell exhaustion

- altered cellular communication

All of these hallmarks have been shown to be negatively impacted by OS (Kawanishi \& Oikawa, 2004; von Zglinicki, 2002; Lopez-Otin et al., 2013; Meiners et al., 2015). These results suggest that oxidative stress be added to the list of hallmarks of aging.

It is beyond the scope of this paper to fully explore the subject of aging. Numerous papers have been written on this subject, with the following representative of these (Junqueira et al., 2004; Andrioli-Sanchez et al., 2005).

\section{Biomarkers of lipid peroxidation}

Biomarkers of specific diseases are typically found in blood, urine, saliva and exhaled breath. These biomarkers can be single component parameters such as blood glucose as an indicator of diabetes, or complex combinations of chemical species, examples of which are: a mixture of 8 different compounds present in set concentrations in exhaled breath as an indicator of gastric cancer (Amal, 2015); or a mixture of 6 serum biomarkers that predict the risk of developing type 2 diabetes (Kolberg, 2009). Disease biomarkers can also be individual chemical species including: F2-Isoprostanes, lipid hydroxides and hydroperoxides, hydroxycholesterols, aldehydes and ketones (Ogino \& Wang, 2007; Niki, 2014; Dalle-Donne et al., 2006; Milne et al., 2005; Yoshida et al., 2013). Of these, malondialdehyde (MDA) level in serum is the most commonly used biomarker of oxidative stress (Ayala et al., 2014; Aflanie et al., 2015). MDA is stable in serum and is readily and accurately analyzed (Hoving, 1992; Nielsen et al., 2007; Grotto, 2009).

\section{MDA from disease and exogenous exposure}

Both ENVDs and INFDs result in the generation of MDA (Sonnerborg et al., 1988). Thus high serum MDA values are predictive of pathogenic disease. People with INFDs have high incidences of other INFDs and with ENVDs. Thus is has been reported that co-morbidities exist between most of the diseases in Table 2 (Zeliger, 2014); and between numerous INFDs (Andresen et al., 2006). Examples of co-morbidities between ENVDs and INFDs include: the flu and neurological disorders (CDC, 2015a; Blanton et al., 2012); Alzheimer's disease and viral infections (Honjo et al., 2009; Maheshwari \& Eslick, 2015; Starakis et al., 2011); HIV and type 2 diabetes (Moni \& Lio, 2014); HIV tuberculosis and malaria with type 2 diabetes (Marais et al., 2013); cardiovascular disease and COPD in a bidirectional manner (Oni \& Unwin, 2015); chronic infections with heart disease (Madjid et al., 2004); and type 2 diabetes with hepatitis C (Guo et al., 2013).

Elevated MDA concentrations are also associated with all of the OS inducing stimuli presented above: toxic chemicals, particles and fibers, diet and food additives, radiation, pharmaceuticals, psychological stress and physical stress.

Table 3 lists the association of diseases and other stimuli with increased MDA serum levels. The data show the elevation of serum MDA as a function of disease or exposure to other OS increasing parameters. As can be seen from the data in Table 3, the presence of disease or exposure to other OS increasing stimuli elevates MDA levels. Though most commonly reported in micrograms per liter $(\mathrm{mcg} / \mathrm{L})$ other units are also reported. For purposes of comparison of affected individuals with healthy or unexposed individuals, all the data in Table 3 have been normalized to 1.0 for control, in each instance.

\section{Discussion}

Historically, most people who became ill with a single disease perished from it. With the progress made in modern medicine, however, this is no longer the case. Mankind has progressed to where many, if not most, diseases can be treated to prolong life. As a consequence of life prolongation, people are now more likely to have multi-morbidities and more likely to die as a result of a disease other than the first one to ail them (Murray et al., 2015).

As can be seen from above, OS and subsequent disease onset as well as aging, is induced by multiple causes. These include environmental exposures, life style choices and requirements as well as the prior presence of disease. OS is directly responsible for the onset of both environmental and infectious diseases, which generate OS and lead to further disease. All of the chemicals in Table 1 cause OS and all of the diseases in Table 2. All of the diseases in Table 2 give rise to OS which triggers the onset of additional disease which, in turn, leads to more OS and multi-morbidities. 
Table 3. Comparison of serum MDA levels of people with disease v. healthy controls and of those with OS-inducing exposures to ones not exposed.

\begin{tabular}{|c|c|c|c|c|}
\hline $\begin{array}{l}\text { Disease/ } \\
\text { Exposure }\end{array}$ & $\begin{array}{c}\text { MDA } \\
\text { affected }\end{array}$ & $\begin{array}{c}\text { MDA } \\
\text { healthy }\end{array}$ & Ratio & Reference \\
\hline Acute COPD & 2.4 & 0.9 & 2.7 & Tug et al., 2004 \\
\hline Stable COPD & 1.2 & 0.9 & 0.9 & Tug et al., 2004 \\
\hline COPD & 1.3 & 0.6 & 2.2 & Stupnytska \& Fetiv, 2014 \\
\hline Adult ADHD & $2.4^{*}$ & $0.4^{*}$ & 6.0 & Bulut et al., 2007 \\
\hline Sepsis & $2.5^{*}$ & $1.1^{*}$ & 2.3 & Lorente 2013 et al., 2013 \\
\hline Sepsis & $3.2^{*}$ & $1.1^{*}$ & 2.9 & Lorente 2013a et al., 2013 \\
\hline CVD & 2.8 & 2.4 & 1.2 & Boaz et al., 1999 \\
\hline OBS & 4.8 & 2.5 & 1.9 & Olusi 2002 \\
\hline Stress & 4.4 & 2.5 & 1.8 & Chellappan et al., 2008 \\
\hline Depression & 2.0 & 0.4 & 5.0 & Baipai et al., 2014 \\
\hline AR & 3.5 & 2.2 & 1.6 & Alsamarai et al., 2009 \\
\hline Asthma & 4.4 & 2.2 & 2.0 & Alsamarai et al., 2009 \\
\hline AR + Asthma & 7.2 & 2.2 & 3.3 & Alsamarai et al., 2009 \\
\hline Met-S & 1.0 & 0.8 & 1.3 & Moreto et al., 2014 \\
\hline BPH & 2.1 & 1.0 & 2.1 & Merendino et al., 2003 \\
\hline Stomach CAN & 2.6 & 0.8 & 3.3 & Bitla et al., 2011 \\
\hline T2D & 2.2 & 1.3 & 1.7 & Tangvarasittichai et al., 2009 \\
\hline T2D & 2.7 & 0.9 & 3.0 & Bhutia et al., 2011 \\
\hline $\mathrm{T} 2 \mathrm{D}+$ Smoker & 3.2 & 0.9 & 3.6 & Bhutia et al., 2011 \\
\hline $\mathrm{T} 2 \mathrm{D}+\mathrm{CVD}$ & 3.7 & 0.9 & 4.1 & Bhutia et al., 2011 \\
\hline T2D & $3.5^{*}$ & $1.9^{*}$ & 1.8 & Mahareen et al., 2010 \\
\hline $\mathrm{T} 2 \mathrm{D}+\mathrm{MI}$ & $5.5^{*}$ & $1.9^{*}$ & 2.9 & Mahareen et al., 2010 \\
\hline Obesity & 2.0 & 0.6 & 3.3 & Yesilbursa et al., 2005 \\
\hline Malnutrition & 2.9 & 1.2 & 2.4 & Ghone et al., 2013 \\
\hline E-coli infection & 4.2 & 2.0 & 2.1 & Karaman et al., 2009 \\
\hline Stomatitis & 3.0 & 2.7 & 1.1 & Khademi et al., 2014 \\
\hline TB & $5.4^{*}$ & $2.1^{*}$ & 2.6 & Kulkarni et al., 2013 \\
\hline IBS & 2.1 & 1.6 & 1.3 & Mete et al., 2013 \\
\hline $\mathrm{IHD}$ & 4.2 & 2.4 & 1.8 & Metta et al., 2015 \\
\hline IHD + smoker & 6.0 & 2.4 & 2.5 & Metta et al., 2015 \\
\hline Smokers & 0.9 & 0.6 & 1.5 & Bloomer 2007 \\
\hline Smokers & 0.7 & 0.6 & 1.2 & Nielsen et al., 1997 \\
\hline Smokers & 3.8 & 2.0 & 1.9 & Shah et al., 2015 \\
\hline Smokers & 1.3 & 0.3 & 4.3 & Sudha et al., 2015 \\
\hline \multirow[t]{4}{*}{ Healthy only data } & * & 0.6 & & Chakravarty \& Rizvi 2011 \\
\hline & & 1.3 & & Hoving et al., 1992 \\
\hline & & 0.8 & & Hu et al., 2006 \\
\hline & & 0.9 & & Bhutia, et al., 2011 \\
\hline Road tar fumes & 1.5 & 0.3 & 5.0 & Sudha et al., 2014 \\
\hline Smoker + road tar & 2.3 & 0.3 & 7.7 & Sudha et al., 2014 \\
\hline Artificial food color & $2.6^{*}$ & $2.1^{*}$ & 1.2 & Cemek et al., 2014 \\
\hline Paint thinner & 2.0 & 1.0 & 2.0 & Halifeoglu et al., 2000 \\
\hline $900 \mathrm{MHz}$ radiation & 8.5 & 7.5 & 1.1 & Dasdag et al., 2012 \\
\hline
\end{tabular}

* Data reported in other units, converted to mcmoles/liter. All data reported to 2 significant figures. Ratios of disease or exposure/controls are indicative of the relative impact of disease or exposure on MDA elevation.

Abbreviations: COPD - chronic obstructive pulmonary disease; CVD - cardiovascular disease; OBS - obesity; AR - allergic rhinitis; Met-S - metabolic syndrome; $\mathrm{BPH}$ - benign prostate hypertrophy; CAN - cancer;

T2D - type 2 diabetes; MI - myocardial infarction; TB - tuberculosis; IBS - irritable bowel syndrome; IDH - ischemic heart disease.
It is hypothesized here that the increase in disease incidence is not due to any one cause, but to all causes that increase OS and that OS from multiple causes is additive. Thus the slope of the curve in Figure 1 for the increase of the incidence of disease with time is directly related to the increases in environmental prevalence of numerous OS-inducing chemicals and the fact that people are living with increased numbers of multi-morbidities that are OS inducing (see below). People have tried to ascribe the increased prevalence of specific diseases to specific environmental causes - including increased exposure to mercury, PCBs, heavy metals, acetaminophen use, etc. but this cannot be done - as it is the sum of OS from all causes that causes disease, and each OS causative agent increases the likelihood of disease onset.

It is further hypothesized that total serum MDA is a valid indicator of the level of oxidative stress in a body and a predictor of disease onset. Credence for these hypotheses comes from the following eight considerations:

\section{Disease - exposure - MDA relationships}

The data in Table 3 clearly show that all causes of OS-related disease induction result in increases in serum MDA levels. These causes include toxic environmental exposures as well as environmental and infectious diseases. As can be seen from the data in Table 3, serum MDA levels increase with disease as well as with other OS inducing exposures.

\section{Additive serum MDA levels}

The data in Table 3 show that those with multiple MDA increasing sources have higher serum MDA levels and that serum MDA levels are additive. The multiple sources can be 2 or more diseases (for example, type 2 diabetes and cardiovascular disease (Bhutia et al., 2011) or myocardial infarction (Mahareen et al., 2010); in 2 or more environmental exposures as in (for example, cigarette smoking and road tar (Bhutia et al., 2011); or a disease and a toxic exposure (for example, type 2 diabetes and cigarette smoking (Bhutia et al., 2011).

Serum MDA data show that controls for different studies of the same disease may have a range of MDA values for "healthy" individuals. For example, the values for healthy subjects being compared to those with diabetes range from 0.9 to $1.9 \mathrm{mcg} / \mathrm{L}$. This is so because the "healthy" people in the different studies most certainly had different exogenous exposures as well as different diets that would account for the range in MDA levels. Nielsen, for example, reported that the serum MDA levels for a healthy individual was found to vary up and down by as much as $19 \%$ over a six day period (Nielsen et al., 1997).

\section{Treatment lowers serum MDA}

Lowering OS by administering antioxidants (Kontush et al., 2001; Jain et al., 2000; Coskun et al., 2006); disease treatment (for example, treating asthma (Bartoli et al., 2011) and diabetes (Wang et al., 2014)) and avoidance of environmental OS inducing agents all lower serum MDA levels. 


\section{Dose response relationship}

There is a dose response relationship (DRR) between exposure levels of OS-inducing chemical toxins and/or the presence of disease and serum MDA levels. This is illustrated by the following examples: There are DRRs between serum MDA levels and: the number of hours of smoking cigarettes (Nielsen et al., 1997); exposures to trichloroethyene and perchloroethyene (Zhu et al., 2005); exposure to air pollution (Romeau et al., 2008); exposures to arsenic, cadmium and mercury (Aflanie et al., 2015); and exposure to ultra violet radiation (Agarwal et al., 1987).

\section{Multi-morbidity}

The multiple causes of OS predict disease multi-morbidity. Since each disease or toxic exposure raises the level OS, additional morbidity is to be anticipated since the incidence of all the diseases in Table 2 and all the chemicals and other exposures in Table 1 are known to be associated with higher OS. Accordingly, one ill with virtually any disease or continually exposed to an OS-inducing agent is at increased risk for additional disease.

Multi-morbidities are associated with stress as one of the co-contributors (Aich et al., 2009). Psychological stress significantly increases infectious disease susceptibility via impact on immune function (Jemmott \& Locke, 1984). Individuals under psychological stress have been shown to have a higher incidence and a greater severity of upper respiratory disease that those with lower stress levels (Aich et al., 2009).

Multi-morbidities of ENVDs are bi-directional. The following examples are illustrative. In those ill with both with hypertension and type 2 diabetes, the first illness incidence was equally split between the two diseases (Sowers \& Epstein, 1995). Diabetes was also found to be bi-directional with depression (Mayo, 2015), and data from multiple studies showed that depression was bi-directional with myocardial infarction (Chi et al., 2014). A wide range of neurological diseases (including Alzheimer's disease and Parkinson's disease) are co-morbid and bi-directional with epilepsy, as are stroke, cardiac, gastrointestinal and respiratory diseases (Gaitatzis et al., 2012). Asthma and anxiety are bi-directional (Lee et al., 2016), as are metabolic syndrome and mental health disorders (including schizophrenia, bipolar disorder, depression, anxiety, attention-deficit/hyperactivity disorder (ADHD) and autism spectrum disorders (Nousen et al., 2013). All of the diseases just mentioned are known to be caused by OS, indicating a common mechanism of induction.

It follows from the above that a chemical that "causes" a disease may only be part of the cause, since it may be only one of several OS contributors. It also follows that the disease that kills need not be the first disease, since an ensuing disease may be a more aggressive killer. For example, chemical sensitivity, which is rarely lethal but is a source of OS, may be followed by T2D, which can cause death. Another example of a primary disease that is generally not lethal is chronic fatigue syndrome.
Though high serum MDA is predictive of the onset of additional morbidity, it is not generally possible to predict a specific disease than can ensue based on serum MDA alone. This is so because there are thousands of different lipophilic cell membranes in the human body, all of which produce MDA upon lipid peroxidation. The disease that ensues depends upon which particular membrane type is attacked (Zeliger \& Lipinski, 2015).

\section{Chronic inflammation}

Chronic inflammation can be caused by chronic disease, continual exposure to exogenous toxins, a regular regimen of some pharmaceuticals, smoking tobacco, living in an area of high air pollution and/or a western style diet. Oxidative stress induces inflammation and inflammation leads to OS, setting up a vicious cycle of chronic inflammation (Reuter et al., 2010). Chronic inflammation increases cancer risk by impacting every step of tumorigenesis from initiation to tumor promotion and ultimately to metastatic progression (Ikemura et al., 2013; Grivennikov et al., 2009; Hanahan \& Weinberg, 2011; Milara \& Cortijo, 2012) and is considered a hallmark of cancer (Diakos et al., 2014; Melnik, 2015; Liu et al., 2014). This connection underscores the importance of limiting the factors that induce oxidative stress and inflammation in preventing the onset of further disease.

\section{Late onset}

Environmental diseases are accumulation disorders that strike as a result of significant contributory factors. These include: genetic predispositions; sequential absorption of OS-producing agents until toxic levels are reached and/ or until all components of toxic mixtures are absorbed in sufficient levels to induce disease; the ability of the body to repair damage is exceeded and its defenses are compromised; or all hallmarks of disease onset are attained (Ayala et al., 2014; Zeliger \& Lipinski, 2015).

\section{Disease prediction}

Actual serum MDA levels are indicative of the presence of disease or disease promoting oxidative stress. A review of the data in Table 3 shows that serum MDA levels are elevated versus controls in those with illness of toxic exposures. Based on the data in Table 3 and numerous other studies, the following scale for serum MDA values in $\mathrm{mcg} / \mathrm{L}$ as predictors of disease is proposed:

\section{Less than 1.20 Indicative of a healthy state}

$1.20-1.40$

$1.40-3.00$

Greater than 3.00 Disease predicted Disease onset probable

These values suggest that asymptomatic individuals with serum MDA levels of 1.20 or greater be evaluated further for disease.

Though MDA predicts disease onset, it alone, cannot predict which disease will come because of the varying exposures, states of disease and the particular one of thousands of different lipophilic membranes in the body which can be attacked by free radicals, each of which may attack a different organ or system. 


\section{Disease prevention}

The discussion above strongly suggests that the key to disease prevention is to eliminate as many of the causes of OS as is possible, for it is the total OS from whatever source(s) that causes disease onset. Such sources can include toxic chemical exposure, chronic inflammation from existing environmental and/or infectious disease and lifestyle choices such as diet and tobacco use. This, prevention can be accomplished by aggressively treating all diseases, by treating symptoms from conditions with intermittent or occasional manifestations such as allergic reactions and by limiting exposures via what are termed here as micro- and macro-preventative measures and the treatment of disease, be it environmental or infectious where possible. It is important that treatment include attention to all morbidities present as well as to all sources of exposures that contribute to OS. It should be noted that the body can recover from occasional high-dose acute levels of OS, but is subject to the onset of disease from chronic elevated levels of OS. Asymptomatic Patients who present with elevated serum MDA levels should be further evaluated to determine the source(s) of their high MDA levels and precautions taken to reduce such sources before the onset of disease, as disease onset will provide additional OS and can lead to further disease.

Micro-preventative measures include exposurelimiting steps that can be undertaken by the individual. These include: lifestyle actions such as adherence to a Mediterranean type diet that is high in antioxidant phytochemicals; carbon-filtering tap water; limiting intake of processed and red meats; avoidance of foods and personal care products that contain preservatives such as triclosan, butylated hydroxy anisole (BHA), butylated hydroxy toluene (BHT) and parabens; limiting exposures to exogenous toxins such as tobacco smoke and pesticides; exercising in times of high air pollution levels; avoiding packaging foods in plastics that exude phthalates and bisphenol A; limiting pharmaceutical use to those medically deemed essential; combating obesity; and seeking prompt medical help when disease strikes.

Macro-preventive measures are societal actions that lead to healthier living. These include: educational programs to produce awareness of environmental hazards to good health; regulatory control of hazardous chemical release, tobacco products, pesticides and chemicalcontaining products; encouragement of the production of organic foods; mandating strict warnings for hazardous materials; and stimulation of green energy production to reduce global warming, which enhances the volatilization of toxic chemicals, increases the rates of environmental chemical reactions which lead to higher levels of ozone and other air pollutants, as well as the increased risk of wildfires which spew large quantities of pollutants into the air.

It has been recently reported that the deleterious effects of obesity linger long after significant weight loss (Stokes \& Preston, 2015). White adipose tissue (WAT) serves as a collector and bio-concentrator of exogenous lipophilic chemicals such as PCBs, chlorinated hydrocarbon pesticides, polynuclear aromatic hydrocarbons. other persistent organic pollutants (POPs) and chemicals that are found in air, water, food and everyday products (Arrebola et al., 2013; Brown et al., 2016). These chemicals partition from WAT to blood serum and serve as a constant supplier of OS-inducing toxins to the blood (Yu et al., 2011; Lind et al., 2013). Rapid weight loss, involving drastic reduction in WAT, results in the release of large quantities of toxic lipophiles with resultant significant systemic OS increase, an event that can lead to the onset of diabetes, cardiovascular, renal, liver and other diseases (Lind et al., 2013; Olusi, 2002; Zeliger, 2013; Zeliger, 2013a; Zeliger, $2013 b)$. Accordingly, gradual weight reduction is preferable to rapid weight loss, to allow for the metabolism and elimination of toxic lipophilic chemicals. It is to noted, however, that many POPs (such as PCBs, dioxins, furans and chlorinated pesticides such as DDT and its metabolite DDE) have very long half lives in the body and may linger up to 30 years or more (Gallo et al., 2011; Yu et al., 2011). This consideration offers an explanation of why the effects of initial obesity linger throughout one's life and the need to prevent obesity throughout life, particularly during childhood and early adulthood.

There are limitations to disease prevention for several reasons and it is not implied here that all disease can be eliminated for three reasons. First, there are genetic differences which protect some and put others at risk for the onset of disease. Second, ignorance, socio-economic status, lifestyle, peer pressure and economic interests of chemical manufacturers, mining operations and intentional polluters act counteractively to prevent chemical exposures. Third, there are conflicting situations where well meaning people on both sides of an issue can reasonably disagree. Two examples of such situations serve as illustrations of this point and the often difficult choices that need to be made. DDT and its metabolite DDE are persistent organic pollutants that are causative agents of OS and disease (Zeliger, 2011). DDT, however, is still in use in parts of the world to control malaria causing mosquitoes. Drinking water is routinely disinfected with chlorine to remove water-borne pathogens. Disinfection byproducts of chlorine treatment, however, are known human toxins that have associated with adverse reproductive effects and diseases including cancer (Tardiff et al., 2006; Bove et al., 2007).

\section{Conclusions}

Virtually all human disease is induced by oxidative stress. Total oxidative stress, from whatever source, be it toxic environmental exposure, the presence of disease, lifestyle choices or combinations of these, increases the incidence of OS. OS leads to lipid peroxidation of lipophilic cell membranes, which in turn produces MDA. Serum MDA level is an additive parameter resulting from all sources of OS and, therefore, is a reliable indicator of total oxidative stress that can be used to predict the onset of disease in clinically asymptomatic individuals and to suggest the 
need for further clinical evaluation and treatment that can prevent much human disease. Routine MDA screening is recommended for addition to annual medical checkup blood work.

\section{REFERENCES}

Abdel-Salam OME, Salem NA, El-Shamarka MES, Hussein JS, Ahmed NAS, ElNagar MES. (2012). Studies on the effects of aspartame on memory and oxidative stress in brain of mice. Eur Rev Med Pharmacol Sci 16: 2092-2101.

Abdullahi M, Larijani B, Rahimi R, Salari P. (2005). Role of oxidative stress in osteoporosis. Summary Therapy 2(5): 787-96.

Abella A, Santoro A, Scotece M, Conde J, Lopez-Lopez V, Lazzaro V et al., (2015). Non-dioxin-like polychlorinated biphenyls (PCB 101, PCB 153 and PCB 180) induce chondrocyte cell death through multiple pathways. Toxicol Lett 234(1): 13-19.

Adedara IA, Abolaji AO, Odion BE, Okwudi IJ, Omoloja AA, Farombi EO. (2014). Impairment of hepatic and renal functions by 2.5 -hexanedione is accompanied by oxidative stress in rats. J Toxicol. 2014: Article ID 239240, 9 pages.

Aflanie I. (2015). Effect of heavy metal on malondialdehyde and advanced oxidation protein products concentration: A focus on arsenic, cadmium and mercury. J Med Bioengen 4(4): 332-37.

Agarwal S, Ghosh A, Chatterjee SN. (1987). Spontaneous release of malondialdehyde from ultraviolet light exposed liposomal membranes. Z Naturforsch 42c: $585-88$.

Aich P, Potter A, Griebel PJ. (2009). Modern approaches to understanding stress and disease susceptibility: a review with special emphasis on respiratory disease. Int J Gen Med 2: 19-32.

Akaike T. (2001). Role of free radicals in viral pathogenesis and mutation. Rev Med Virol 11(2): 87-101.

Alsamarai AM, Alwan AM, Ahmad AH, Salib MA, Salih JA, Aldabagh MA et al. (2009). The relationship between asthma and allergic rhinitis in the Iraqi population. Allergology, Int 58: 649-55.

Andresen HM, Regueira HT, Leighton F. (2006). Oxidative stress in critically ill patients. Rev Med Chil 134(5): 649-56.

Andriollo-Sanchez M, Hininger-Favier I, Meunier N, Venneria E, O'Connor JM, Maiani G, Coudray C, Roussel AM. (2005). Age-related oxidative stress and antioxidant parameters in middle-aged and older European subjects: the ZENITH study. Eur J Clin Nutr 59(Suppl 2): S58-62.

Arcavi L, Benowitz NL. (2004). Cigarette smoking and infection free. Arch Int Med 164(20): 2206-16.

Arrebola JP, Pumarega J, Gasull M, Fernandz MF,Martin-Olmedo P, MolinaMolina JM et al., (2013). Adipose tissue concentrations of persistent organic pollutants and prevalence of type 2 diabetes in adults from Southern Spain. Environ Res 122: 31-37.

Aryal M, Pandeya A, Gautam N, Baral N, Lamsal M, Majhi S et al., (2007). Oxidativew stress in prostate hyperplasia. Nepal Med Coll J 9(4): 222-24.

Ayala A, Munoz MF, Arguelles S. (2014). Lipid peroxidation: production, metabolism, and signaling mechanosms of malondialdehyde and 4-hydroxy2-nonenal. Oxidative Med Cellular Longevity 2014: Article ID 360438, 31 pages.

Azeez OM, Akhigbe RE, Anigbogu CN. (2013). Oxidative stress in rat kidney exposured to petroleum hydrocarbons. J Nat Sci Biol Med 4(1): 149-54.

Bagaitkar. Demuth DR, Scott DA. (2008). Tobacco use increases susceptibility to bacterial infection. Tobacco Induced Diseases 4: 12.

Baillie-Hamilton PF. (2002). Chemical toxins: a hypothesis to explain the global obesity epidemic. J Altern Complement Med 8(2): 185-92.

Baipai A, Verma AK, Srivastava M, Srivastave R. (2014). Oxidative stress and major depression. J Clin Diagn Res 8(12): CC04-077.

Bamonti F, Novembrino C, Ippolito S, Soresi E, Ciani A, Lonati S et al., (2006). Increased free malondialdehyde concentrations in smokers normalise with a mixed fruit and vegetable juice concentrate: a pilot study. Clin Chem Lab Med 44(4): 391-95.

Banerjee BD, Seth V, Bhattacharya A, Pasha ST, Chakraborty AK. (1999). Biochemical effects of some pesticides on lipid peroxidation and free-radical scavengers. Toxicol Lett 107(1-3): 33-47.
Barber SC, Mead RJ, Shaw PJ. (2006). Oxidative stress in ALS: a mechanism of neurodegeneration and a therapeutic target. Biochim Biophy Acta 1762(1112): 1051-67.

Bartoli ML, Novelli F, Costa I, Malagrino L, Melosini E, Bacci S et al., (2011). Malondialdehyde in exhaled breath condensate as a marker of oxidative stress in different pulmonary diseases. Mediators of Inflamm. 2011: Article ID 891752, 7 pages

Basaranoglu M, Basaranoglu G, Bugianesi E. (2015). Carbohydrate intake and non alcoholic fatty liver disease: fructose as a weapon of mass destruction. HepatoBiliary Surg Nutr 4(2): 109-116.

Bashir S, Harris G, Denman MA, Blake DR, Winyard PG. (1993). Oxidative DNA damage and cellular stress in human autoimmune disease. Ann Rheumatic Dis 52: 659-66.

Benotti MJ, Trenholm RA, Vanderford BJ, Holady JC, Stanford BD, Snyder SA. (2009). Pharmaceuticals and endocrine disrupting compounds in U.S. drinking water. Environ Sci Tech 43(3): 597-603.

Bhattacharyya A, Chattopadhyay R, Mitra S, Crowe SE. (2014). Oxidative stress: an essential factor in the pathogenesis of gastrointestinal mucosal diseases. Physiol Rev 94: 329-54.

Bhutia Y, Ghosh A, Sherpa ML, Pal R, Kumar-Mohanta P. (2011). Aerum malondialdehyde level: surrogate stress marker in the Sikkinmese diabetics. $J$ Nat Sci Biol Med 2(1): 107-112.

Bickers DR, Athar M. (2006). Oxidative stress in the pathogenesis of skin diseases. J Invest Dermatol 126(12): 2565-75.

Bitla AR, Reddy EP, Sambasivaih K, Suchitra M, Reddy VS, Rao S. (2011). Evaluation of plasma malondialdehyde as a biomarker in patients with carcinoma of the stomach. Biomed Res 22(1): 63-68.

Blanton L, Peacock G, Cox C, Jhung M, Finelli L Moore C. (2012). Neurologic disorders among pediatric death associated with the (2009) pandemic influenza. Pediatrics 130(3): 390-96.

Bloomer RJ. (2007). Decreased blood antioxidant capacity and increased lipid peroxidation in young cigarette smokers compared to nonsmokers: impact of dietary intake. Nutr J 6: 39.

Boaz M, Matas Z, Biro A, Katzir Z, Green M, Fainaru M, Smetana S. (1999). Serum malondialdehyde and prevalent cardiovascular disease in hemodialysis. Kidney Int 56: 1078-83.

Bouayed J, Rammal J, Soulimani R. (2009). Oxidative stress and anxiety. Oxidative Med Cellular Longevity 2(2): 63-67.

Bove GE Jr, Rogerson PA, Vena JE. (2007). Case control study of the geographic variability of exposure to disinfectant byproducts and risk for rectal cancer. Int J Health Geog 6: 18.

Bouhafs RK, Jastrand C. (1999). Phagocyte-induced lipid peroxidation of lung surfactant. Pediatr Pulmonol 27(5): 322-27.

Bouvard V, Loomis D, Guyton KZ, Grosse Y. (2015). Carcinogencity of consumption of red and processed meat. Lancet Oncol 16(16): 1599-1600.

Bovalino S, Charleson G, Szoeke C. (2016). The impact of red and processed meat consumption on cardiovascular disease risk in women. Nutrition 32(3): 349-54.

Brkic S, Tomic S, Maric D, Novakov MA, Turkulov V. (2010). Lipid peroxidation is elevated in female patients with chronic fatigue syndrome. Med Sci Monit 16(12): CR628-32.

Brown NS, Bicknell R. (2001). Hypoxia and oxidative stress in breast cancer. Oxidative stress: its effects on the growth, metastatic potential and response to therapy of breast cancer. Breast Cancer Res 3: 323-27.

Brown RE, Sharma AM, Ardern Cl, Mirdarmadi P, Mirdarmadi P, Kuk JL. (2016). Secular differences in the association between caloric intake, macronutirent intake, and physical activity with obesity. Obes Res Clin Pract. 10(3): 243-55.

Browne MA, Crump P, Niven SJ, Teuten E, Tonkin A, Galloway T, Thompson R. (2011). Accumulation of microplastic on shorelines worldwide: sources and sinks. Environ Sci Technol 45(21): 9175-79.

Bulut M, Selek S, Gergerlioglu HS, Savas HA, Yilmaz HR, Yuce M, Ekici G. (2007). Malondialdehyde levels in adult attention-deficit hyperactivity disorder. J Psychiatry Neurosci 32(6): 435-38.

Cabezas-Opazo FA, Vergara-Pulgar K, Perez MJ, Jara C Osorio-Fuentealba C, Quintanilla RA. (2015). Mitochondrial dysfunction contributes to the pathogenesis of Alzheimer's disease. Oxid Med Cell Longev 2015: Article ID 509654, 12 pages. 
Cemek M, Buyukokuroglu ME, Sertkaya F, Alpdagras S, Hazini, A, Onul A, Gones S. (2014). Effects of food color additives on antioxidant functions and bioelement contents of kidney and brain tissues in rats. J Food Nutr Res 2(10): 686-91.

CDC. (2015). Flu and people with diabetes. Centers for Disease Control (2015). http: //www.cdc.gov/flu/diabetes.

CDC (2015)a. Leading causes of death. Centers for Disease control (2015) http: //www.cdc.gov/nchs/fastats/leading-causes-of-death.htm

Cemek M, Dede S, Bayiroglu F, Caksen H, Cemek F, Yuka K. (2005). Oxidant and antioxidant levels in children with acute otitis media and tonsillitis: a comparative study. Int J Pediatr Otorhinolaryngo/ 69(6): 823-27.

Cemek M, Buyukokuroglu ME, Alpdagtas S, Hazini A, Onul A, Gones S. (2014), Effects of food color additives on antioxidant functions and bioelement contents of liver, kidney and bran tissues in rats. J Food Nutr Res 2(10): 68691.

Chakravarty S, Rizvi SI. (2011). Day and night GSH and MDA levels in healthy adults and effects of different doses of melatonin on these parameters. Int J Cell Biol 2011: Article ID 404591, 5 pages.

Chaput JP, Despres JP, Bouchard C, Tremblay A. (2008). The association between sleep duration and weight gain in adults: a 6-year prospective study for the Quebec family study. Sleep 31(4): 517-23.

Chellappan D, Joseph J, Shabi MM, Krishnamoorthy G, Ravindran D, Uthrapathy $S$ et al., (2008). Psycho-emotional stress - a cause of coronary artery disease. Acta Scientiae Vet 36(2): 133-39.

Chen CC, McCarl BA. (2001). An investigation of the relationship between pesticide usage and climate change. Climate Change 50: 475-87.

Chi MJ, Yu E, Liu WW, Lee MC, Chung MH. (2014). The bidirectional relationship between myocardial infarction and depressive disorders. Int J Cardiol 177(3): 854-59.

Choi YJ, Seelbach MJ, Pu H, Eum SY, Cen L, Zhang B et al., (2010). Polychlorinated biphenyls disrupt intestinal integrity via NADPH oxidase-induced alterations of tight junction protein expression. Environ Health Perspect 118(7): 976-81.

Chole RH, Patil RN, Basak A, Palandurkar K, Bhowate R. (2010). Estimation of serum malondialdehyde in oral cancer and precancer and its association with health individuals, gender, alcohol, and tobacco abuse. J Cancer Res Ther 6(4): 487-91.

Cichoz-Lach H, Michalek A. (2014). Oxidative stress as a crucial factor in liver diseases. World J Gastroentero/ 20(25): 8082-91.

Cohen S, Janicki-Deverts D, Doyle WJ. (2015). Self-related health in healthy adults and susceptibility to the common cold. Psychosomatic Med 77(9): 959-68

Colborn T, Dumanoski D, Myers JP. (1996). Our Stolen Future. Dutton Penguin Books, New York.

Corradi M, Rubinstein R, Andreoli R, Manini P, Caglieri A, Poli D et al., (2003). Aldehydes in exhaled breath condensate of patients with chronic obstructive pulmonary disease. Am J Resp Critical Care Med 167: 1380-86

Coscun O, Yuncu M, Kanter M, Buyukbas S. (2006). Ebelsen protects against oxidative and morphological effects of high concentration chronic toluene exposure on rat sciatic nerves. Eur J Gen Med 3(2): 64-72.

Csoka AB, Szyf M. (2009). Epigenetic side-effects of common pharmaceuticals: a potential new field in medicine and pharmacology. Med Hypothesis 73(5): $770-80$.

Crous-Bou M, Fung TT, Prescott J, Julin B, Du M, Sun Q et al., (2014). Mediterannean diet and telomer length in Nurses' Health Study: population based cohort study. BMJ 349: g6674.

Cui J, Xiao Y, Shi YH, Wang B, Le GW. (2012). Lipoic acid attenuates high-fatinduced oxidative stress and B-cell-related immune depression. Nutrition 28(3): $275-80$.

Dale-Donne I, Rossi R, Colombo R, Giustarini D, Milzani A. (2006). Biomarkers of oxidative damage in human disease. Clin Chem 52: 601-623.

Darmon N, Pelissier MA, Heyman M, Albrecht R, Desjeux JF. (1993). Oxidative stress may contribute to the intestinal dysfunction of weanling rats fed a low protein diet. J Nutr 123(6): 1068-75.

Dasdag S, Akdag MZ, Kizil G, Kizel M, Cakir DU, Yokus B. (2012). Effect of 900 $\mathrm{MHz}$ radio frequency radiation on beta amyloid protein, protein carbonyl and malondialdehyde in the brain. Electromag Biol Med 31(1): 67-74.

Davies KJA. (1995). Oxidative stress: the paradox of aerobic life. Biochem Soc Symp 61: 1-31.
Deavall DG, Martin EA, Horner JM, Roberts R. (2012). Drug-induced oxidative stress and toxicity. J Toxicol. 2012: Article ID 645460, 13 pages.

Delfino RJ, Staimer N, Tjoa T, Gillen DL, Schauer JJ, Shafer MM. (2013). Airway inflammation and oxidative potential of air pollutant particles in a pediatric asthma panel. J Expo Sci Environ Epidemiol 23(5): 466-73.

Deshpande N, Kandi S, Muddeshwar M, Ramana KV. (2014). Effect of alcohol consumption and oxidative stress and its role in DNA damage. Am J Biomedical Res 2(1): 7-10.

Diakos $\mathrm{Cl}$, Charles KA, McMillan DC, Clarke SJ. (2014). Cancer-related inflammation and treatment effectiveness. Lancet Oncol 15(11): e493-503.

Dillioglugil MO, Mekik H, Muezzinoglu B, Ozkan TA, Demir CG, Dillioglugil O. (2012). Blood and tissue nitric oxide and malondialdehyde are prognostic indicators of localized prostate cancer. Int Urol Nephrol 44(6): 1691-96.

Doi K, Uetsuka K. (2011). Mechanisms or mycotoxin-induced neurotoxicity through oxidative stress-associated pathways. Int J Mol Sci 12(8): 5213-37.

Donaldson K, Li XY, MacNee W. (1998). Ultrafine (nanometre) particle mediated lung injury. J Aerosol Sci 29(5-6): 553-60

Donaldson K, Tran L, Jimenez LA, Duffin R, Newby DE, Mills N et al., (2005). Combustion-derived nanoparticles: a review of their toxicology following inhalation exposure. Particle and Fiber Toxicol. 2: 10

Dwyer, DJ, Belencky PA, Yang JH, MacDonald IC, Martell JD, Takahashi N et al. (2014). Antibiotics induce redox-related physiological alterations as part of their lethality. Proc Natl Acad Sci U S A 111(20): E2100-9.

Elgazar AF. (2013). Effects of butylated hydroxytoluene and butylated hy droxyanisole against hepatotoxicity induced by carbon tetrachlorine in rats. World Applied Sci J 22(1): 63-69.

El-Wahab HM, Moram GS. (2013). Toxic effects of some synthetic food colorants and/or flavor additives on male rats. Toxicol Ind Health 29(2): 224-32.

Epel ES, Blackburn EH, Lin J, DhabharFS, Adler NE, MOrrow JD, Cawthon RM. (2004). Accelerated telomer shortening in response to life stress. Proc Nat Acad Sci USA 101(49): 17312-15.

Esmekaya MA, Ozer C, Seyhan N. (2011). 900 MHz pulse-modulated radiofrequency radiation induces oxidative stress on heart, lung, testis and liver tissues. Gen Physiol Biophys 30(1): 84-89.

Faden Al, Loane DJ. (2015). Chronic neurodegeration after traumatic brain injury: Alzheimer Disease, Chronic Traumatic Encephalopathy. Neurotherapeutics 12: 143-50.

Falagas ME, Kompoti M. (2006). Obesity and infection. Lancet Infect Dis 6(7): 438-46.

Federico A, Morgillo F, Tuccillo C, Ciardiello F, Loguercio C. (2007). Chronic inflammation and oxidative stress in human carcinogenesis. Int $J$ Cancer 121(11): 2381-86.

Fernandez-SAnchez A, Madrigal-Santillan E, Bautista M, Esquivel-Soto J, Morales-Gonzalez A, Durante-Montiel I et al., (2011). Inflammation, oxidative stress and obesity. Int J Mol Sci 12(5): 3117-32.

Forbes JM, Coughlan MT, Cooper ME. (2008). Oxidative stress as a major culprit in kidney disease in diabetes. Diabetes 57: 1146-54.

Furukawa S, Fujita T, Shimabukuro M, Iwaki M, Yamada Y, Nakajima $Y$ et al., (2004). Increased oxidative stress in obesity and its impact on metabolic syndrome. J Clin Investigat 114(12): 1752-61.

Gaitatzis A, Siscodiva SM, SAnder JW. (2012). The somatic comorbidity of epilepsy: a weighty but often unrecognized burden. Epilepsia 53(8): 1282-93.

Galle J. (2001). Oxidative stress in chronic renal failure. Nephrol Dial Transplant 16(11): 2135-37.

Gallo MV, Schell LM, DeCaprio AP, Jacobs A. (2011). Levels of persistent or ganic pollutant and their predictors among young adults. Chemosphere $\mathbf{8 3}$ 1374-82.

Ghone RA, Suryakar AN, Kulhalli PM, Bhagat SS, Padalkar RK, Karnik AC et al. (2013). A study of oxidative stress biomarkers and effect of oral antioxidant supplementation in severe acute malnutrition. J Clin Diag Res 7(10): 214648.

Gong J, Zhe T, Kipen H, Wang G, Hu M, Ohman-Strikland P et al., (2013). Malondialdehyde in exhaled breath condensate and urine as a biomarker of air pollution induced oxidative stress. J Expo Sci Environ Epidemio/ 23(3): 322-27.

Griendling KK, Garret A, Fitzgerald MD. (2003). Oxidative stress and cardiovascular injury. Part I: Mechanism and in vivo monitoring of ROS. Circulation 108: 1912-16.

Grivennikov SI, Greten FR, Karin M. (2010) Immunity, inflammation and cancer. Cell 140(6): 883-99. 
Grover SA, Kaouache M, Rempel P, Joseph L, Dawes M, Lau DCW, Lowensteyn I. (2015). Years of lost and healthy life-years lost from diabetes and cardiovascular disease in overweight and obese people: a modeling study. Lancet Diabetes Endocrin 3(2): 114-22.

Guarner C, Soriano G. (2005). Bacterial translocation and its consequences in patients with cirrhosis. Eur J Gastroenterol Hepatol 17: 27-31.

Guo X, Jin M, Yang M, Liu K, Li JW. (2011) Type 2 diabetes mellitus and the risk of hepatitis C virus infection: a systematic review. Sci Rep 3: 2981.

Guven N, Ozturk B, Sayal A, Ozeturk A, Ulutin T. (1999). Lipid peroxidation and antioxidant system in the blood of cancerous patients with metastasis. Cancer Biochem Biophys 17(1-12): 155-62.

Halifeoglu I, CAnatan H, Ustundag B, Ilhan N, Inanc F. (2000). Effect of thinner inhalation on lipid peroxidation and some antioxidant enzymes of people working with paint thinner. Cell Biochem Funct 18(4): 263-67.

Halonen JI, Hansell AL, Gulliver J, Morley D, Blangiardo M, Fecht D, et al. (2015). Road traffic noise is associated with increased cardiovascular morbidity and mortality and all-cause mortality in London. Eur Heart J 36(39): 2653-61.

Hanahan D, Weinberg RA. (2011). Hallmarks of cancer: the next generation. Cell 144: 646-74.

He F, Zuo L. (2015). Redox roles of reactive oxygen species in cardiovascular diseases. Int J Mol Sci 16(11): 27770-80.

Honjo K van Reekum R, Verhoeff NP. (2009). Alzheimer's disease and infection: do infectious agents contribute to progression of Alzheimer's disease? Alz Dement 5(4): 348-60.

Hou L, Joyce BT, Gao T, Liu L, Zheng Y, Penedo FJ et al., (2015). Blood telomere length attrition and cancer developmemnt in the normative aging study cohort. EBioMedicine 132(6): 591-96.

Hoving EB, Laing C, Rutgers HM, Teggeler M, van Doormaal JJ, Muskiet FA. (1992). Optimized determination of malondialdehyde in plasma lipid extracts using 1,3-diethy-2-thiobarbituric acid: influence of detection method and relations with lipids and fatty acids in plasma from healthy adults. Clin Chim Acta 208(1-2): 63-76.

Hu Y, Block G, Norkus EP, Morrow JD, Dietrich M, Hudes M. (2006). Relations of glycemic index and glycemic with plasma oxidative stress markers. Am J Clin Nutr 84: 70-76.

Hughes DA. (1999). Effects of dietary antioxidants on the immune function of middle-aged adults. Proc Nutr Soc 58: 79-84.

Ikemura M, Nishikawa M, Kusamori K, Fukuoka M, Yamashita F, Hashida M. (2013). Pivotal role of oxidative stress in tumor metastasis under diabetic conditions in mice. J Control Release 170(2): 191-97.

Jain SK, McVie R, Smith T. (2000). Vitamin E supplementation restores glutathione and malondialdehyde to normal concentrations in eryhtrocytes of type 1 diabetic children. Diabetes Care 23(9): 1389-94.

Jain S, Chaves SS. (2011). Obesity and influenza. CID 53: 422-23.

Jaurand MC, Pairon JC. (2011). Toxicity of particles: a brief history. Nanoethics and Nanotechnology. doi: 10.1007/978-3-642-20177-6_1.

Jemmott JB, 3rd, Locke SE. (1984). Psychosocial factors, immunologic mediation, and human susceptibility to infectious diseases: how much do we know? Psychol Bull 95(1): 78-108.

Jeng HA, Pan CH, Diawara N, Chang-Chien GP, Lin WY, Huang CT et al., (2011). Polycyclic aromatic hydrocarbon-induced oxidative stress and lipid peroxidation in relation to immunological alteration. Occup Environ Med 68(9): 653-58.

Junqueira VB, Barros SB, Chan SS, Rodrigues L, Giavarotti L, Abud RL, Deucher GP. (2004). Aging and oxidative stress. Mol Aspects Med 25(1-2): 5-16.

Kalghati S, Spina CS, Costello JC, Liesa M, Morones-Ramirez JR, Slomovic S et al., (2013). Bactericidal antibiotics induce mitochondrial dysfunction and oxidative damage in mammalian cells. Sci Transl Med. 5(192): 192ra85.

Kalkan G, Sechin HY, Duygu F, Akbas A, Ozyurt H, Sahin M. (2014). Oxidative stress in patients with acute urticaria. Cutan Ocul Toxicol 33(2): 109-14.

Kambia N, Dine T, Gressier B, Frimat B, Cazin JL, Luyckx M et al., (2011). Correlation between exposure to phthalates and concentrations of malondialdehyde in infants and children undergoing cyclic parenteral nutrition. $J$ Parenteral Enteral Nutr 35(3): 395-401.

Kantor ED, Rehm CD, Haas JS, Chan AT, Giovannucci EL. (2015). Trends in prescription drug use among adults in the United States from 1999-2012. JAMA 314(17): 1818-30.

Karaman U, Kiran TR, Colak C, Iraz M, Celik T, Karabulut AB. (2009). Serum malondialdehyde, glutathione and nitric oxide levels in patients infected with entamoeba coli. Int J Medicine Med Sci 1(5): 235-37.
Karbowik-Lewinska M, Szosland J, Kokoszko-Bilska A, Stepniak J, Zasada K Gesing A, Lewinski A. (2012). Direct contribution of obesity to oxidative damage to macromolecules. Neuro Endocrinol Lett 33(4): 453-61.

Katona P, Katona-Apte J. (2008). The interaction between nutrition and infection. Clin Pract 46: 1582-88.

Kaur K, Chauhan V, Gu F, Chauhan A. (2014). Bispenol A induces oxidative stress and mitochondrial dysfunction in lymphoblasts from children with autism and unaffected siblings. Free Rad Biol Med 76: 25-33.

Kawashini S, Oikawa S. (2004). Mechanism of telomere shortening by oxidative stress. Ann NY Acad Sci 1019: 278-84.

Kayama Y, Raaz U, Jagger A, Adam M, Schellinger IN, Sakamoto M et al., (2015). Diabetic cardiovascular disease induced by oxidative stress. Int J Mol Sci 16(10): 25234-63.

Khademi H, Khozeimeh F, Tavangar A, Amini S, Ghalayani P. (2014). The serum and salivary level of malondialdehyde, vitamins $A, E$, and $C$ in patient with recurrent aphthous stomatitis. Adv Biomed Res 3: 246.

Khansari N, Shakiba Y, Mahmoudi M. (2009). Chronic inflammation and oxidative stress as a major cause of age-related diseases and cancer. Recent Pat Inflamm Allergy Drug Discov 3(1): 73-80.

Kim KJ, Yoon KY, Hong HD, Lee BY. (2015). Role of red ginseng in defense against the environmental heat stress in Sprague Dawley rats. Molecules 20: $20240-53$.

Kim RO, Rhee JS, Won EJ, Lee KW, Kang CM, Lee YM, Lee JS. (2011). Ultraviolet $B$ retards growth, induces oxidative stress, and modulates DNA repairrelated gene and heat shock protein gene expression in the monogonont rotifer, Brachionus sp. Aquat Toxicol 101(3-4): 529-39.

Kim YJ, Kim EH, Hahm KB. (2012). Oxidative stress in inflammation-based gastrointestinal tract diseases: challenges and opportunities. J Gastroenterol Hepatol 27(6): 1004-10.

Kitahara CM, Flint AJ, Berrington de Gonzalez A, Bernstein L, Brotzman M, Maclnnis RJ et al., (2014). Association between class III obestity (BMI of 40 $59 \mathrm{~kg} / \mathrm{m}$ ) and mortality: a pooled analysis of 20 prospective studies. PLoS Med 11(7): e1001673.

Knaapen AM, Borm PJA, Albrecht C, Schins RPF. (2004). Inhaled particles and lung cancer. Part A: mechanisms. Int J Can 109: 799-809.

Knight TR, Fariss MW, Farhood A, Jaeschke H. (2003). Role of lipid peroxidation as a mechanism of liver injury after acetamonophen overdose in mice. Toxicol Sci 76: 229-36.

Kobylewki S, Jacobson MF. (2012). Toxicology of food dyes. Int J Occup Environ Health 18(3): 220-46.

Kontush A, Mann U, Arit S, Ujeyl A, Luhrs C, Muller-Thomsen T, Beisiegel U. (2001). Influence of vitamin $E$ and $C$ supplementation on lipoprotein oxidation in patients with Alzheimer's disease. Free Rad Biol Med 31(3): 345-54.

Kruk J, Kubasik-Kladna K, Aboul-Enein HY. (2015). The role oxidative stress in the pathogenesis of eye diseases: current status and dual role of physical activity. Mini Rev Med Chem 16(3): 241-57.

Kulkarni R, Deshpande A, Saxena R, Saxena K. (2013). A study of serum malondialdehyde and cytokine in tuberculosis patients. J Clin Diagnostic Res 7(10): 2140-42

Kumagai S, Jikimoto T, Saegusa J. (2003). Pathological roles of oxidative stress in autoimmune diseases. Rinsho Byori 51(2): 126-32 [Japanese].

Kurutas EB, Ciragil P, Gul M, Kilinc M. (2005). The effects of oxidative stress in urinary tract infection. Mediators of Inflamm 4: 242-44.

Lee YC, Lee CT, Lai YR, Chen VC, Stewart R. (2016). Association of asthma and anxiety: a nationwide popilation-based study in Taiwan. J Affect Discord 189: 98-105

Li G, Zhang LL, Lu D, Wu P, Zheng W. (2004). Occupational exposure to welding fume among welders: alterations of manganese, iron, zinc, copper and lead in body fluids and the oxidative stress status. J Occup Environ Med 46(3): 241-48.

Li P, Wang B, Sun F, Li Y, LI Q, Lang H et al., (2015). Mitchondrial respiratory dysfunctions of blood mononuclear cells link with cardiac disturbance in patients with early-stage heart failure. Sci Rep 5: 10229.

Lind PM, Lee DH, Jacobs DR, Salihovic S, van Bavel B, Wolff MS, Lind L. (2013). Circulating levels of persistent organic pollutants are related to retrospective assessment of life-time weight change. Chemosphere 90(3): 998-1004.

Liu J, Qu W, Kadiiska MB. (2009). Role of oxidative stress in cadmium toxicity and carcinogenesis. Toxicol Appl Pharmacol 238(3): 209-14.

Liu YC, Zou XB, Chai YF, Yao YM. (2014). Macrophage polarization in inflammatory diseases. Int J Biol Sci 10(5): 520-29. 
Liu Z, Liu Y, Song Y, Zhang X, Wang S, Wang Z. (2014). Systemic oxidative stress biomarkers in chronic periodontitis: a meta analysis. Disease Markers 2014: Article ID 931083, 10 pages.

Lodovici M, Bigagli E. (2011). Oxidative stress and air pollution exposure. J Toxicol 2011: Article ID 487074, 9 pages

Lorente L, Martin MM, Abreu-Gonzalez P, Dominguez-Rodriguez A, Labarta L, Diaz C, Sole-Violan J et al., (2013). Prognostic value of malondialdehyde serum levels in sever sepsis: a multicenter study. PLoS One 8(1): e53741.

Lorente L, Martin MM, Abreu-Gonzalez P, Dominguez-Rodriguez A, Labarta L, Diaz C, Sole-Violan J et al., (2013)a. Sustained high serum malondialdehyde levles are associated with severity and mortality in septic patients. Critical Care 17: R290.

Lou J, Jin L, Wu N, Tan Y, Song Y, Gao M et al., (2013). DNA damage and oxidative stress in human $B$ lymphoblastoid cells after combined exposure to hexavalent chromium and mickel compounds. Food Chem Toxicol 55: 53340.

Luongo G, Avagyan R, Hongyu R, Ostman C. (2015). The washout effect during laundry on benzothiazole, benzotriazole, quinoline and their derivatives in clothing textiles. Environ Sci Pollut Res Int 23(3): 2537-48.

Lustig RH, Mulligan K, Noworolski SM, Tai VW, Wen MJ. Erkin-Cakmak A et al., (2015). Isocaloric fructose restriction and metabolic improvement in children with obesity and metabolic syndrome. Obesity 24: 453-460.

Madebo T, Lindtjorn B, Aukrust P, Berge RK. (2003). Circulating antioxidants and lipid peroxidation products in untreated tuberculosis patients in Ethiopia. Am J Clin Nutr 78: 117-22.

Madjid M, Aboshady I, Awan I, Litovsky S, Casscells SW. (2004). Influenza and cardiovascular disease. Is there a relationship? Texas Heart Inst J 31(1): 4-13.

Maheshwari P, Eslicj GD. (2015). Bacterial infection and Alzheimer's disease: a metal-analysis. J Alz Dis 43(3): 957-66.

Mahreen R, Mohsin M, Ishaq M. (2012). Significantly increased levels of serum malondialdehyde in type 2 diabetics with myocardial infarction. Int J Diabetes Dev Ctries 30(1): 49-51.

Manna P, Jain SK. (2015). Obesity, oxidative stress, adipose tissue dysfunction, and the associated health risks: causes and therapeutic strategies. Metab Syndr Relat Discord 13(10): 423-44.

Marais BJ, Lonroth K, Lawn SD, Migliori GB, Mwaba K, Glaziou P et al., (2013). Tuberculosis comorbidity with communicable and nonp-communicable diseases: integrating health services and control efforts. Lancet Infect Dis 13(5): 436-48.

Mayo P. (2015). Prevention and management of comorbid diabetes and depression. Nurs Stand 30(8): 46-54.

McEwen BS. (2006). Sleep deprivation as a neurobiologic and physiologic stressor: allostasis and allostatic load. Metabolism 10(Suppl 2): S20-23.

Meiners S, Eickelberg O, Konigshoff M. (2015). Hallmarks of ageing lung. Eur Respir H 45(3): 807-27.

Melnik BC. (2015). MiR21: an environmental driver of malignant melanoma? J Trans Med 13: 202.

Merendino RA, Salvo F, Saija A, Di Pasquale G, Tomaino A, Minciullo PL et al., (2003). Malondialdehyde in benign prostate hypertrophy: a useful marker? Mediators Inflamm 12(2): 127-28.

Mete R, Tulubas F, Oran M, Yilmaz A, Avci BA, Yildiz K et al., (2013). The role of oxidants and reactive nitrogen species in irritable bowel syndrome: a potential etiological explanation. Med Sci Monit 19: 762-66.

Metta S, Basalingappa DR, Uppala S, Mitta G. (2015). Erythrocyte antioxidant defenses against cigarette smoking in ischemic heart disease. J Clin Diagnost Res 9(6): BC08-BC11.

Milara J, Cortijo J. (2012). Tobacco, inflammation, and respiratory tract cancer. Curr Pharmaceut Design 18: 3901-38

Miller MW. Sadeh N. (2014). Traumatic stress, oxidative stress and posttraumatic stress disorder: meurodeneration and accelerated-aging hypothesis. Mol Psychiatry 19(11): 1156-62.

Milne GL, Seal JR, Havnilla CM, Wijtmans M, Porter NA. (2005). Identification and analysis of products formed from phospholipids in the free radical oxidation of low density lipoproteins. J Lipid Re 46(2): 307-19.

Moni MA, Lio P. (2014). Nwtwork-based analysis of comorbidities risk during an infection: SARS and HIV case studies. Bioinformatics 15: 333.

Moreto F, de Oliveira E, Manda RM, Burini RC. (2014). The higher plasma malondialdehyde concentrations are determined by metabolic sybdrome-related glucolipotoxicity. Oxidat Med Cellular Longev 2014: Article ID 505368, 7 pages.
Mujahid A, Akiba Y, Toyomizu M. (2007). Acute stress induces oxidative stress and decreases adaptation in your leghorn cockerels by downregulation of avian uncoupling protein. Poult Sci 86(2): 364-71.

Nahta R, Al-Mulla F, Al-Temaimi R, Amedie A, Andrade-Vieira R, Bay SN et al., (2015). Mechanisms of environmental chemicals that enable the cancer hallmark of evasion of growth suppression. Carcinogenesis 36(Suppl 1): S2S18.

Neel BA, Sargis RM. (2011). The paradox of progress: environmental disruption of metabolism and the diabetes epidemic. Diabetes 60: 1838-48.

Neustadt J, Pieczenik SR. (2008). Medication-induced mitochondrial damage and disease. Mol Nutr Food Res 52(7): 780-88.

Nielsen F, Mikkelsen BB, Niesen JB, Andersen HR, Grandjean P. (1997). Plasma malondialdehyde as biomarker for oxidative stress: reference interval and efforts of life-style factors. Clin Chem 43(7): 1209-14.

Niki E. (2014). Biomarkers of lipid peroxidation in clinical material. Biochim Biophys Acta 1840(2): 809-17.

Ning Li, Sioutas C, Cho A, Schmitz D, Misra C, Sempf J et al., (2003). Ultrafine particulate pollutants induce oxidative stress and mitochondrial damage. Environ Health Perspect 111(4): 455-60.

Nisbet C, Yarim GF, Ciftci A, Ceneciz S, Ciftci G. (2007). Investigation of serum nitric oxide and malondialdehyde levels in cattle infected with Brucella abortus. Ankar Univ Vet Fak Derg 54: 159-63.

Noguti J, Anderson ML, Cirelli C, Ribeiro DA. (2013). Oxidative stress, cancer and sleep deprivation: is there a logical link in this association? Sleep Breath 17(3): 905-10.

Nousen EK, Franco JG, Sullivan EL. (2013). Unraveling the mechanisms responsible for the comorbidity between metabolic syndrome and mental health disorders. Neuroendocrinology 98(4): 254-66.

Nunes B, Carvalho F, Guilhermino L. (2006). Effects of widely used pharmaceuticals and a detergent on oxidative stress biomarkers of the crustacean Artemia parthogenetica. Chemosphere 62(4): 581-94.

Okayama Y. (2005). Oxidative stress in allergic and inflammatory skin diseases. Curr Drug Targets Inflamm Allergy 4(4): 517-19.

Ogino K, Wang Wang DH. (2007). Biomarkers of oxidative/nitrosative stress: an approach to disease prevention. Acta Med Okayama 61: 181-89.

Olusi SO. (2002). Obesity is an independent risk factor for plasma lipid peroxidation and depletion of erythrocyte cytoprotic enzymes in humans. Int J Obes 26: 1159-64.

Onil T, Unwin N. (2015). Why the communicable/non-communicable disease dichotom is problematic for public health control strategies: implications of multimorbidity for public health systems in an era of health transition. Int Health 7(6): 390-9.

Pan Y, Johnson AR, Rea WJ. (1987). Aliphatic hydrocarbon solvents in chemically sensitive patients. Clin Eco/ V(3): 126-31.

Pandey MK, Mittra P, Maheshwari P. (2013). Oxidative stress in epilepsy with comorbid psychiatric illness. Nat J Physiol Pharm Pharmacol 3(1): 92-96.

Park DY, Ahn YT, Huh CS, McGregor RA, Choi MS. (2013). Dual probiotic strains suppress high fructose-induced metabolic syndrome. World J Gastroenterol 19(2): 274-83.

Parkin DM, Stiller CA, Draper GJ, Bieber CA. (1988). The international incidence of childhood cancer. Int J Cancer 42(4): 511-20.

Patil AJ, Bhagwat VR, Patil JA, Dongre NN, Ambekar JG, Jailkhani R, Das KK. (2006). Effect of lead (Pb) exposure on the activity of superoxide dismutase and calatase in battery manufacturing workers (BMW) of Western Maharashtra (India) with reference to heme biosynthesis. Int J Environ Res Pub Health 3(4): 329-37.

Patterson Jr. DG, Wong LY, Turner SP, Depietro ES, McClure PC, Cash TP et al., (2009). Levels in the U.S. population of those persistent organic pollutants (2003-2004) included in the Stockholm convention or in other long-range transboundry air pollution agreements. Environ Sci Tech 43(4): 1211-18.

Patterson RM, Germolec DR. (2006).Gene expression alterations in immune system pathways following exposure to immunosuppressive chemcials. Ann N Y Acad Sci 1076: 718-27.

Pham-Huy LI, He H, Pham-Huy C. (2008). Free radicals, antioxidants in disease and health. Int J Biomed Sci 4(2): 89-96.

Pohanka M. (2013). Role of oxidative stress in infectious diseases. A review. Folia Microbiol (Praha) 58(6): 503-13.

Popovic-Dragonjic L, Jovanovic M, Vrbic M, Konstantinovic L, Kostic V, Dragonjic I. (2011). Antioxidant defense and oxidative stress in children with acute hepatitis A. Ann Saud Med 31(3): 258-62. 
Pritchard C, Rosenorn-Lanng E. (2015). Neurological deaths of American adults (55-74) and the over 75's by sex compared with 20 Western countries 1989-2010: cause for concern. Surgical Neurol Int 6: 123.

Quio Y, Sun J, Ding Y, Le G, Shi Y. (2013). Alterations of the gut microbia i highfat diet mice is strongly linked to oxidative stress. Appl Microbil Biotechnol 97(4): 1689-97.

Rajah T, Chow SC. (2015). Suppression of human T cell proliferation mediated by the Cathepsin B inhibitor, z-FA-FMK is due to oxidative stress. PLoS One 10(4): e0123711.

Ramanathan L, Gulyani S, Nienhuis R, Siegel JM. (2002). Sleep deprivation decreases superoxide dismutase activity in rat hippocampus and brainstem. Neuroreport 13(1): 1387-90.

Reuter S, Gupta SC, Chaturvedi MM, Aggarwal BB. (2010). Oxidative stress, inflammation, and cancer: how are they linked? Free Rad Biol Med 49(11): 1603-16.

Rodayan A, Afana S, Segura PA, Sultana T, Metcalfe CD, Yargeau V. (2016). Linking drugs in wastewater to contamination of surface and drinking water. Environ Toxicol Chem. 35(4): 843-9.

Romano AD, Serviddio G, de Matthaeus A, Bellantil F, Vendemiale G. (2010). Oxidative stress and aging. J Nephrol Supp/ 15: S29-36.

Romieu I, Barraza-Villarreal A, Escamilla-Nunez C, Almstrand AC, Diaz-Sanchez D, Sly PD et al., (2008). Exhaled breath malondialdehyde as a marker of effect of exposure to air pollution in children with asthma. J Allerge Clin Immunol 121(4): 903-9.

Salim SY, Kaplan GG, Madsen KL. (2014). Air pollution effects on the gut microbia. Gut microbes 5(2): 215-19.

Salzano S, Checconi P, Hanschmann EM, Lillig CH, Bowler LD, Chan P et al., (2014). Linkage of inflammation and oxidative stress via release of glutathionylated peroxiredoxin-2, which acts as a danger signal. PNAS 111(33): 12157-62.

Salzman R, Pacal L, Tomandl J, Kankov K, Tothova EGal B et al., (2009). Elevated malondialdehyde correlates with the extent of primary tumor and predicts poor prognosis of oropharyngeal cancer. Anticancer Res 29: 4227-32.

Schneider D, Manzan MA, Crawford RB, Chen W, Kaminski NE. (2008). 2,3,7,8-tetrachlorodibenzo-p-dioxin-mediated impairment of $B$ cell differentiation involves dysregulation of paried box 5 (Pax5) isoform, Pax 5a. J Pharmacol Exp Ther 326(2): 463-74.

Semenkov VF, Michalski Al, Sapozhnikov AM. (2015). Heating and ultraviolet light activate anti-stress gene functions in humans. Front Genetics. 6: 245

Shah AA, Khand F, Khand TU. (2015). Effect of smoking on serum xanthine oxidase, malondialdehyde, ascorbic acid and a-tocopherol levels in healthy male subjects. Pak J Med Sci 31(1): 146-49.

Sonnerborg A, Carlin G, Akerlund B, Jarstrand C. (1988). Increased production of malondialdehyde in patients with HIV infection. Scand J Infect Dis 20(3): 287-90.

Sowers JR, Epstein M. (1995). Diabetes mellitus and associated hypertension, vascular disease and nephropathy. Hypertension 26: 869-79.

Splettstoesser WD, Schuff-Werner P. (2002). Oxidative stress in phagocytes-"the enemy within." Microsc Res Tech 57(6): 441-55.

Starakis J, Panos G, Koutras A. Mazokopakis EE. (2011). Pathogens and chronic or long-term neurologic disorders. Cardiovasc Hematol Disord Drug Targets 11(1): 40-52.

Steenland K, Stayner L. (1997). Cancer Causes and Control 8(3): 491-503.

Stevens LJ, Kuczek T, Burgess JR, Stochelski MA Arnold LE, Galland L. (2013). Mechanisms of behavioral, atopic, and other reactions to artificial food colors in children. Nutr Rev 71(5): 268-81.

Stokes A, Preston SH. (2015). Revealing the burden of obesity using weight histories. PNAS 113(3): 572-577.

Stossel TP, Mason RJ, Smith AL. (1974). Lipid peroxidation by human blood phagocytes. J Clin Invest 54(3):638-45.

Stupnyska G, Fediv O. (2014). Mechanisms of local and systemic inflammation in chronic obstrutive pulmonary disease with comorbid hypertension and obesity. Int J Scientific Tech Res 3(5): 218-22.

Sudha S, Sree JS, Saranya RS, Varun S. (2014). Evaluation of DNA damage and oxidative stress in road pavement workers occupationally exposed to polycyclic aromatic hydrocarbons. Int Conf Adv Agri Biol Environ Sci Oct 15-16, (2014). http: //dx.doi.org/1015242/IICBE.C1014023.

Surapaneni KM, Venkatatamana G. (2007). Status of lipid peroxidation, glutathione, ascorbic acid, vitamin $\mathrm{E}$ and antioxidant enzymes in patients with osteoarthritis. Indian J Med Sci 61(1): 9-14.
Suzuki H, Nishihiro T, Tsugawa S, Hibi T. (2012). Roles of oxidative stress in stomach disorders. J Clin Biochem Natr 50(1): 35-39.

Tangvarasittichai S, Poonsub P, Tangvarasittichai O, Sirigulsatien V. (2009). Serum levels of malondialdehyde in type 2 diabetes mellitus Thai subjects. Siriraj Med J 61: 20-23.

Tradiff RG, Carson ML, Ginevan ME. (2007). Updated weight of evidence for an association between adverse reproductive and developmental effects and exposure to disinfection byproducts. Regul Toxicol Pharacol 45(2): 185205

Taysi S, Uslu C, Akcay F, Sutbeyaz MY. (2003). Malondialdehyde and nitric oxide levels in the plasma of patients with advanced laryngeal cancer. Surg Today 33(9): 651-54.

Thiering E, Heinrich J. (2015) Epidemiology of air pollution and diabetes. Trend Endocrinol Metab 26(7): 384-94.

Tominaga H, Kodama S, Matsuda N, Suzuki K, Watanabe M. (2004). Involvement of reactive oxygen species (ROS) in the induction of genetic instability by radiation. J Radiat Res 45(2): 181-88.

Torun AN, Kulaksizouglu S, Kulaksizouglu M, Pamuk BO, Isbilen E, Tutuncu NB. (2009). Serum total antioxidant status and lipid peroxidation marker maloldialdehyde levels in overt and subclinial hypothyroidism. Clin Endocrinol (Oxf) 70(3): 469-74.

Tremellen K. (2008). Oxidative stress and male infertility - a clinical perspective. Human Reprod Update 14(3): 243-58.

Trouba KJ, Hamadeh HK, Amin RP, Germolec DR. (2002). Oxidative stress and its role in skin disease. Antioxid Redox Signal 4(4): 665-73.

U.S. Energy and information administration. U.S. annual energy outlook, (2014). May 7, (2014). http://www.eia.gov/forcasts/ieo/Accessed May 6, 2016. von Zglinicki T. (2002). Oxidative stress shortens telomeres. Trends Biochem Sci 27(7): 339-44.

Valyl-Nagy T, Dermody TS. (2005). Role of oxidative damage in the pathogenesis of viral infections of the nervous system. Histol Histopathol 20: 957-67.

Vandanmagsar B, Youm YH, Ravussin A, Galgani JE, Stadler K, Mynatt RL et al., (2011). The NALP3/NLRP3 inflammasome instigates obesity-induced autoinflammation and insulin resistance. Nat Med 17(2): 179-88.

Veraldi A, Costantini AS, Bolejack V, Miligi L, Vineis P, van Loveren H. (2006). Immunotoxic effects of chemicals: a matrix for occupational and environmental epidemiological studies. Am J Int Med 49(12): 1046-55.

Vitale G, Salvioli S, Franceschi C. (2013). Oxidative stress and aging endocrine system. Nat Rev Endocrin 9(4): 228-40.

Vu BG, Stach CS, Kulhankova K, Salgado-Pabon W, Klingelhutz AJ, Schlievert PM. (2015). Chronic superantigen exposure induces systemic inflammation, elevated bloodstream endotoxin, and abnormal glucose tolerance in rabbits: possible role in diabetes. Mbio 6(2): e02554.

Wallace RB, Salive ME. (2013). The dimentions of multiple chronic conditions: where do we go from here? A commentary on the special collection of preventing chronic disease. Centers for Disease Control and Prevention. Prev Chronic Dis 10: 130104.

Wang Y, Beydoun MA. (2007). The obesity epidemic in the United States gender, age, socioeconomic, racial/ethnic, and geographical characteristics: A systemic review and meta-regression analysis. Epidemiologic Rev 29(1): 6-28.

Wang CH, Chang RW, Ko YH, Tsai PR, Wang SS, Chen YS et al., (2014). Prevention of arterial stiffening by using low-dose atorvastatin in diabetes is associated with decreased malondialdehyde. PLoS One 9(3): e90471.

Wang J, Luo X, Xu B, Wei J, Zhang Z, Zhu H. (2011). Elevated oxidative damage in kitchen workers in Chinese restaurants. J Occup Health 53: 327-33.

Watkins DJ, Ferguson KK, Anzolota Del Toro LV, Alshawabkeh AN, Cordero JF, Meeker JD. (2015). Associations between urinary phenol and paraben concentrations and markers of oxidative stress and inflammation among pregnant women in Puerto Rico. Int J Hygiene Environ Health 2: 212-19.

Webb C, Twedt O. (2008). Oxidative stress and liver disease. Vet Clin North Am Anim Pract 38(1): 125-35.

Williams DL. (2008). Oxidative stress and the eye. Vet Clin North Am Anim Pract 38(1): 179-92.

Xu GJ, Kula T, Xu Q, Li MZ, Vernon SD. Ndung'n T et al., (2015). Comprehensive serological profiling of human populations using a synthetic human virome. Science 348: aaa0698.

Yang RL, Shi YH, Hao G, Li W, Le GW. (2008). Increasing oxidative stress with progressive hyperlipidemia in human: relation between malondialdehyde and atherogeni index. J Clin Biochem Nutr 43: 154-58. 
Yang YJ, Hong YC, Oh SY, Ha EH. (2009). Bisphenol A exposure is associated with oxidative stress and inflammation in postmenopausal women. Environ Res 109(6): 797-801.

Yesilbursa D, Serdar Z, Serdar A, Sarac M, Coskun S, Jale C. (2005). Lipid peroxides in obese patients and effects of weight loss with orlistat on lipid peroxides levels. Int J Obesity 29: 142-45.

Yoshida Y, Umeno A, Shichiri M. (2013). Lipid peroxidation biomarkers for evaluating oxidative stress and assessing antioxidant capacity in vivo. J Clin Biochem Nutr 52(1): 9-16.

Yu GW, Laseter J, Mylander C. (2011). Persistent organic pollutants in serum and several different fat compartments in humans. J Environ Public Health 2011: 417980.

Zaki MH, Akuta T, Akaike T. (2005). Nitric oxide-induced nitrative stress involved in microbial pathogenesis. J Pharmacol Sci 98: 117-29.

Zeliger HI. (2003).Toxic effects of chemical mixtures. Arch Environ Health 58(1): 23-29.

Zeliger HI. (2004). Unexplained cancer clusters: common threads. Arch Environ Health 59(4): 172-76.

Zeliger HI. (2011). Human toxicology of chemical mixtures, 2nd ed. Elsevier, London.
Zeliger HI, Pan Y, Rea WJ. (2012). Predicting co-morbidities in chemically sensitive individuals from exhaled breath analysis. Interdiscip Toxicol 5(3): 123-26.

Zeliger HI. (2012a). Statin use and risk of diabetes. Arch Int Med 171(11): 89697.

Zeliger HI. (2013). Lipophilic chemical exposure as a cause of type 2 diabetes. Rev Environ Health 28(1): 9-20.

Zeliger HI. (2013a). Lipophilic chemical exposure as a cause of cardiovascular disease. Interdiscip Toxicol 6(2): 55-62.

Zeliger HI. (2013b). Exposure to lipophilic chemicals as a cause of neurological impairments, neurodevelopmental disorders and neurodegenerative diseases. Interdiscip Toxicol 6(3): 103-110.

Zeliger HI. (2014). Co-morbidities of environmental diseases: a common cause. Interdiscip Toxicol 7(3): 117-122.

Zeliger HI, Lipinski B. (2015). Physiochemical basis of human degenerative disease. Interdiscip Toxicol 8(1): 15-21.

Zeliger HI, Possidente B, Drake AG. (2015a). Co-morbidity of multiple chemical sensitivity (MCS) and chronic fatigue syndrome (CFS): which comes first. Pub Health Prevent Med 1(3): 108-11.

Zhu QX, Shen T, Ding R, Liang ZZ, Zhang XJ. (2005). Cytotoxicity of trichlorethylene and perchloroethylene on normal human epidermal keratinocytes and protective role of vitamin E. Toxicology 209(1): 55-67. 